\title{
CO emission and export from Asia: an analysis combining complementary satellite measurements (MOPITT, SCIAMACHY and ACE-FTS) with global modeling
}

\author{
S. Turquety ${ }^{1}$, C. Clerbaux ${ }^{1,2}$, K. Law ${ }^{1}$, P.-F. Coheur ${ }^{2}$, A. Cozic ${ }^{3}$, S. Szopa ${ }^{3}$, D. A. Hauglustaine ${ }^{3}$, J. Hadji-Lazaro ${ }^{1}$, \\ A. M. S. Gloudemans ${ }^{4}$, H. Schrijver ${ }^{4}$, C. D. Boone ${ }^{5}$, P. F. Bernath ${ }^{5,6}$, and D. P. Edwards ${ }^{7}$ \\ ${ }^{1}$ Université Paris 6, CNRS, Service d'Aéronomie/IPSL, Paris, France \\ ${ }^{2}$ Spectroscopie de l'atmosphère, Chimie Quantique et Photophysique, Université Libre de Bruxelles, Brussels, Belgium \\ ${ }^{3}$ Laboratoire des Sciences du Climat et de l'Environnement/IPSL, CEA, CNRS, UVSQ, Gif-sur-Yvette, France \\ ${ }^{4}$ SRON Netherlands Institute for Space Research, Utrecht, The Netherlands \\ ${ }^{5}$ Department of Chemistry, University of Waterloo, Waterloo, Ontario, Canada \\ ${ }^{6}$ Department of Chemistry, University of York, Heslington, York, UK \\ ${ }^{7}$ Atmospheric Chemistry Division, National Center for Atmospheric Research, Boulder, CO, USA
}

Received: 13 November 2007 - Published in Atmos. Chem. Phys. Discuss.: 31 January 2008

Revised: 18 July 2008 - Accepted: 12 August 2008 - Published: 3 September 2008

\begin{abstract}
This study presents the complementary picture of the pollution outflow provided by several satellite observations of carbon monoxide (CO), based on different observation techniques. This is illustrated by an analysis of the Asian outflow during the spring of 2005, through comparisons with simulations by the LMDz-INCA global chemistry transport model. The CO observations from the MOPITT and SCIAMACHY nadir sounders, which provide vertically integrated information with excellent horizontal sampling, and from the ACE-FTS solar occultation instrument, which has limited spatial coverage but allows the retrieval of vertical profiles, are used. Combining observations from MOPITT (mainly sensitive to the free troposphere) and SCIAMACHY (sensitive to the full column) allows a qualitative evaluation of the boundary layer $\mathrm{CO}$. The model tends to underestimate this residual compared to the observations, suggesting underestimated emissions, especially in eastern Asia. However, a better understanding of the consistency and possible biases between the MOPITT and SCIAMACHY CO is necessary for a quantitative evaluation. Underestimated emissions, and possibly too low lofting and underestimated chemical production in the model, lead to an underestimate of the export to the free troposphere, as highlighted by comparisons with MOPITT and ACE-FTS. Both instruments ob-
\end{abstract}

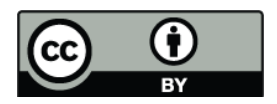

Correspondence to: $\mathrm{S}$. Turquety (solene.turquety@aero.jussieu.fr) serve large trans-Pacific transport extending from $\sim 20^{\circ} \mathrm{N}$ to $\sim 60^{\circ} \mathrm{N}$, with high upper tropospheric $\mathrm{CO}$ observed by ACEFTS above the eastern Pacific (with values of up to $300 \mathrm{ppbv}$ around $50^{\circ} \mathrm{N}$ at $500 \mathrm{hPa}$ and up to $\sim 200 \mathrm{ppbv}$ around $30^{\circ} \mathrm{N}$ at $300 \mathrm{hPa}$ ). The low vertical and horizontal resolutions of the global model do not allow the simulation of the strong enhancements in the observed plumes. However, the transport patterns are well captured, and are mainly attributed to export from eastern Asia, with increasing contributions from South Asia and Indonesia towards the tropics. Additional measurements of $\mathrm{C}_{2} \mathrm{H}_{2}, \mathrm{C}_{2} \mathrm{H}_{6}$ and $\mathrm{HCN}$ by ACE-FTS provide further information on the plume history. $\mathrm{C}_{2} \mathrm{H}_{2}$ and $\mathrm{C}_{2} \mathrm{H}_{6}$ enhancements are well correlated with the $\mathrm{CO}$ plumes, indicating common sources and rapid trans-Pacific transport. HCN observations show that the biomass burning contributes mainly at latitudes lower than $\sim 40^{\circ} \mathrm{N}$. This study provides a first step towards a full combination of complementary observations, but also highlights the need for a better evaluation of consistency between the datasets in order to allow precise quantitative analyses.

\section{Introduction}

Asia is one of the most important pollution source regions. While anthropogenic emissions from North America and Europe appear to be stabilizing or decreasing, emissions from

Published by Copernicus Publications on behalf of the European Geosciences Union. 
Asia have increased rapidly in the past decade, becoming the largest contribution (Richter et al., 2005; Akimoto, 2003). Asian energy consumption has more than doubled since the 1980s due to population growth, rapid industrialization and increasing transportation, causing significant enhancement in the emissions over this region (Streets et al., 2000, 2006; Ohara et al., 2007). In addition to the degradation of regional air quality, it is now recognized that the long range transport of pollution from Asia, both from fossil fuel and biomass burning, has a strong influence on the chemical composition of the troposphere over the Pacific Ocean and downwind continents (e.g. Wild and Akimoto, 2001; Jaffe et al., 1999, 2004; Heald et al., 2003; Bertschi et al., 2004; de Gouw et al., 2004; Hudman et al., 2004). This issue has been the focus of a number of recent aircraft campaigns (TRACE-P in 2001 (Jacob et al., 2003), ITCT-2k2 in 2002 (Parrish et al., 2004), INTEX-B in 2006). Satellite measurements have also been a valuable tool for evaluating Asian emissions (Martin et al., 2003; Arellano et al., 2004; Pétron et al., 2004; Heald et al., 2004) and monitoring trans-Pacific transport (Heald et al., 2003, 2006; Allen et al., 2004; Edwards et al., 2004; Hudman et al., 2004). Current global model simulations of carbon monoxide (CO) show a significant underestimate throughout the Northern Hemisphere compared to satellite observations from the MOPITT/Terra instrument suggesting a missing source year round (Shindell et al., 2006), which could be explained by too low emissions in eastern Asia in the current inventories.

In this study, we explore the information on the Asian pollution outflow provided by complementary satellite observations of $\mathrm{CO}$ using comparisons with simulations from the global chemical transport model LMDz-INCA (Hauglustaine et al., 2004). CO is produced as a result of incomplete combustion and the oxidation of methane and non-methane hydrocarbons (NMHC) initiated mainly by the hydroxyl radical $(\mathrm{OH})$. It is principally removed by reaction with $\mathrm{OH}$. It is a toxic gas at high concentration, currently regulated by air quality standards worldwide as a major ozone precursor. It also contributes to climate change through its effect on ozone and methane chemistry. Furthermore, its relatively long lifetime, of the order of several weeks in the free troposphere, makes it an ideal tracer of the transport of pollution.

$\mathrm{CO}$ is routinely measured by several satellite borne instruments. Nadir looking remote sensors allow the retrieval of global CO distributions with a good spatio-temporal resolution, either from measurements in the thermal infrared spectral region, with MOPITT on board the Terra satellite since 2000 (Edwards et al., 2004; Deeter et al., 2003), AIRS on board Aqua since 2002 (McMillan et al., 2005), TES on board Aura since 2004 (Rinsland et al., 2006a, Luo et al., 2007), and IASI on board MetOp since 2006 (Turquety et al., 2004, Clerbaux et al., 2007), or from measurements in the near-infrared with SCIAMACHY on board ENVISAT since 2002 (Buchwitz et al., 2004, Frankenberg et al., 2005; Gloudemans et al., 2005). However, the nadir geometry pro- vides vertically integrated information, implying limited vertical resolution. $\mathrm{CO}$ retrievals in the thermal infrared spectral range are characterized by a maximum sensitivity in the free troposphere with low sensitivity in the boundary layer and less than two independent pieces of information on the vertical profile, while the near-infrared allow sensitivity down to the Earth's surface but provides only total column measurements. Buchwitz et al. (2007) use the difference between SCIAMACHY and MOPITT CO to infer lower tropospheric columns, and show clear enhancements close to source regions.

In addition to these nadir observations, instruments using solar occultation, such as the ACE-FTS on board SCISAT since 2003 (Bernath et al., 2005; Clerbaux et al., 2005, 2008a), or emission in a limb viewing geometry, such as MIPAS/ENVISAT (Funke et al., 2007) or MLS/Aura (Pumphrey et al., 2007), allow the retrieval of CO profiles with an improved vertical resolution, but with a poorer horizontal coverage than nadir instruments. Of particular interest for this work investigating tropospheric pollution is ACEFTS, which allows probing down to the middle troposphere in cloud free conditions (Clerbaux et al., 2005, 2008a). Several recent studies have shown the value of limb and solar occultation data for tropospheric chemistry studies (Dufour et al., 2007; Folkins et al., 2006; Rinsland et al., 2006b; Coheur et al., 2007; von Clarmann et al., 2008). In particular, the $\mathrm{CO}$ measurements from MLS/Aura and ACE-FTS have been used to analyze the trapping of pollution in the Asian monsoon anticyclone (Li et al., 2005; Park et al., 2008). The MLS/Aura CO measurements have recently been used for the study of transport from Asia (Jiang et al., 2007). They analyze the variability in the measured upper tropospheric $\mathrm{CO}$ using emission climatology and meteorological conditions and show that upper tropospheric CO does not only depend on the surface emissions but also on the importance of deepconvection and intensity of horizontal winds. While surface emissions peak during the boreal spring, they find that the upper tropospheric $\mathrm{CO}$ is largest during the summer due to stronger convection.

There is increasing interest in the scientific community for the definition of future missions in particular - in the combination of different spectral regions and observation geometries in order to gain vertical resolution. While previous studies focused on either nadir or limb observations, we examine the complementary views of the Asian outflow provided by different observation techniques using global chemistry transport model simulations. Therefore, the solar occultation measurements from the ACE-FTS and the nadir observations from MOPITT and SCIAMACHY are analyzed.

This analysis is focused on spring 2005. Two reasons motivated the choice of this time period. First, several studies have shown that spring corresponds to the maximum in Asian outflow due to active cyclonic activity and strong westerly winds. During this season, the Asian pollution can be transported across the Pacific in 5 to 10 days (e.g. Jaffe et 


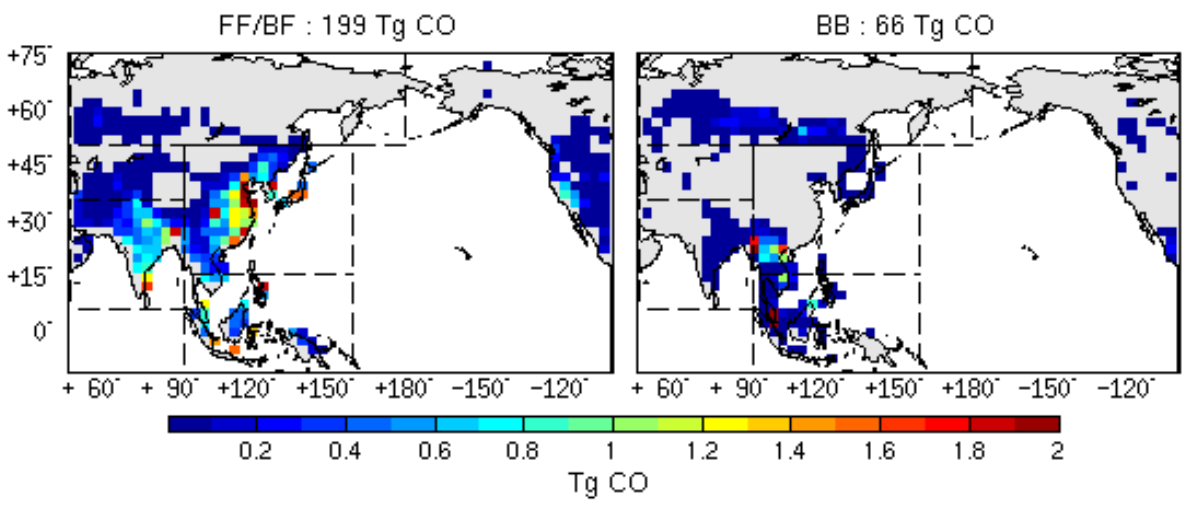

Fig. 1. Anthropogenic (left) and biomass burning (right) $\mathrm{CO}$ emissions, mapped onto the LMDz-INCA horizontal resolution $\left(3.75^{\circ} \times 2.5^{\circ}\right.$ grid $)$, used for the period March-April-May 2005. The black dashed lines indicate the limits of the regions of Asia used for the tagged regional CO simulation with LMDz-INCA.

al., 1999; Liang et al., 2004) with the strongest transport in the middle troposphere (e.g. Bey et al., 2001; Stohl et al., 2002). Secondly, the mid-latitudes of the Northern Hemisphere were well covered by ACE-FTS during this time period.

After a brief description of the global model and a first validation against MOZAIC aircraft measurements, the satellite observations from ACE-FTS, MOPITT and SCIAMACHY are presented, as well as an intercomparison of the available $\mathrm{CO}$ measurements over Asia and the Pacific. Asian outflow and transport is then investigated using the different types of $\mathrm{CO}$ satellite measurements. The origin of the exported air masses is further explored using ACE-FTS observations of acetylene $\left(\mathrm{C}_{2} \mathrm{H}_{2}\right)$, ethane $\left(\mathrm{C}_{2} \mathrm{H}_{6}\right)$ and hydrogen cyanide ( $\mathrm{HCN})$.

\section{Global CO simulation with the LMDz-INCA model}

This analysis of the trans-Pacific transport of $\mathrm{CO}$ is based on comparisons between the available satellite observations and simulations from the LMDz-INCA global chemistry transport model. LMDz-INCA couples the general circulation model (GCM) LMDz (Laboratoire de Météorologie Dynamique, zoom) and the INCA (Interactive Chemistry and Aerosols) chemistry module (Hauglustaine et al., 2004; Folberth et al., 2006). Here, the LMDz version 4 and INCA version 2 are used, in the nudged version of the model, driven by meteorological fields (winds and temperature) from the ECMWF reanalyses (ERA15). The simulations were performed with the standard horizontal resolution of $3.75^{\circ}$ in longitude $2.5^{\circ}$ in latitude on 19 vertical levels extending from the surface to $3 \mathrm{hPa}$, using Emanuel's convection scheme (Emanuel and Zivkovic-Rothman, 1999).

INCA describes the tropospheric oxidation of NMHC and $\mathrm{CH}_{4}$ through 332 chemical reactions using 86 chemical species. In addition to the species commonly included in this chemical scheme, regional CO tracers have been included to track the origin of $\mathrm{CO}$. In particular, the emissions from five regions in Asia are transported independently in the model (Fig. 1). Comparisons between LMDz-INCA and surface CO observations from the NOAA Earth System Research Laboratory (ESRL) Global Monitoring Division (GMD) network (Novelli et al., 1992) for a time period extending from 1997 and 2001 has shown the ability of the model to simulated the interannual variability of CO (Szopa et al., 2007). While meteorology explains most of the variability in the tropics, it is explained by biomass burning and meteorological conditions at high latitude stations. LMDz-INCA participated in the $\mathrm{CO}$ intercomparison exercise by Shindell et al. (2006) and gave results close to the global average.

In this study, the anthropogenic emissions from the EDGAR 3.2 inventory (Olivier and Berdowski, 2001) are used. Recent analyses have shown that Asian emissions are too low in current inventories (Arellano et al., 2004; Heald et al., 2004; Pétron et al., 2004; Streets et al., 2006; Ohara et al., 2007). In order to minimize the effect of this underestimate, the total Asian emissions of $\mathrm{CO}$ have been scaled using the inverse modeling results of Pétron et al. (2004) for the corresponding regions, which was based on the MOPITT observations for the year 2001. The resulting emissions are shown in Fig. 1. Total $\mathrm{CO}$ emitted above this region is estimated to $395 \mathrm{Tg} \mathrm{CO} /$ year (56\% larger than the standard EDGAR total). The main emission regions are eastern China, Korea, Japan, and India. Monthly biomass burning emissions from the Global Fire Emissions Database (GFED) version 2 (van der Werf et al., 2006) corresponding to the studied time period were used. During the spring of 2005, fires were mainly burning in south-east Asia and, with a smaller contribution, in southern Siberia and Canada (Fig. 4).

Before using the model simulations as an intermediate to better understand the information provided by the different satellite observations on the Asian outflow, we have first evaluated the $\mathrm{CO}$ simulations against in situ measurements. 
The comparisons with the surface CO data from the GMD network show good general agreement. For the downwind sites (Mauna Loa, Midway), the agreement is very good for background conditions (difference lower than $\sim 2 \%$ ) and the model shows enhancements attributed to Asia corresponding to peaks in the observations. However, LMDz-INCA underestimates these peaks by $\sim 18 \%$. For the high latitude sites (Barrow, Cold Bay, Shemya Island) the difference between model and observations is lower than $4 \%$ in April, but increases as the season progresses to $\sim 20 \%$ underestimate at the end of May. This could be due to an underestimate of the emissions from the Russian fires which increased at this time period, or to too high photochemical destruction at high latitudes in the model. However, the correlation is very good $\left(r^{2}=0.85\right)$ for sites over the Pacific, highlighting the model's ability to capture variability in the surface $\mathrm{CO}$, and thus giving us confidence in our simulation of long-range transport from Asia during this time period.

Evaluation of the vertical distributions of $\mathrm{CO}$ was undertaken using the vertical profiles from the MOZAIC aircraft data, measured during take off and landing of commercial aircraft (Nedelec et al., 2003). Figure 2 shows comparisons above Asia (Bangkok, Hong-Kong, Shanghai and Tokyo) and western North America (Vancouver and San Francisco) averaged over the available measurements during the spring of 2005. The model tends to overestimate CO in the upper troposphere and lower stratosphere (UTLS), which could be due to too low vertical resolution in the model or to too large exchange between the troposphere and the stratosphere. The agreement between $\sim 500 \mathrm{hPa}$ and $300 \mathrm{hPa}$ is generally good, with a small tendency to underestimate $\mathrm{CO}$ (up to $\sim 9 \%$ in San Francisco). On the contrary, the model clearly underestimates $\mathrm{CO}$ in the middle troposphere (by 10 to $20 \%$ between 850 and $500 \mathrm{hPa}$ ), although it remains within the measured variability, and at the surface (by less than $20 \%$ except above Bangkok, where CO is underestimated by $49 \%$ below $850 \mathrm{hPa}$ ). Part of this underestimate is explained by the relatively low horizontal resolution of the model. Underestimate at the surface may also be explained by the fact that MOZAIC measures $\mathrm{CO}$ above airports, hence in highly polluted areas which are not well resolved by global models. In the free troposphere, it is likely due to an underestimate of the contribution from long-range transport. The variability in the model simulation is expected to be lower than in the observations since the model cannot capture the magnitude of strong transport events, due to the lack of vertical and horizontal resolution, but also to overestimated diffusion in the model (Hauglustaine et al., 2004). The regional CO tracers, also shown in Fig. 2, indicate that Asia is the preponderant contribution at all levels locally, and in the middle and upper troposphere above western America. In the following sections, we will analyze the additional information provided by complementary space-borne instruments on the Asian pollution outflow.

\section{Satellite CO observations}

\subsection{Solar occultation observations from ACE-FTS}

ACE-FTS (Atmospheric Chemistry Experiment Fourier Transform Spectrometer) was launched in August 2003 on board the Canadian ACE satellite (also known as SCISAT1 ), and measures the infrared (IR) radiation in solar occultation mode (Bernath et al., 2005). Up to thirty occultation sequences are recorded daily, during fifteen sunrises and fifteen sunsets. The solar occultation technique allows the retrieval of a wide range of trace species due to the high signal to noise ratio of the measurements, and the retrieval of vertical profiles with a good vertical resolution from the midtroposphere to the thermosphere (Coheur et al., 2007). A global fit approach is used, described in Boone et al. (2005), in which all parameters are retrieved simultaneously using a general non-linear least-squares method. The early ACEFTS CO retrievals are described and characterized in Clerbaux et al. (2005). In this analysis, we use the data from the version 2.2 of the retrieval algorithm. A full validation of the CO retrievals is provided in Clerbaux et al. (2008a). The ACE-FTS vertical sampling is $\sim 2 \mathrm{~km}$ in the mid and upper troposphere, and the accuracy of the $\mathrm{CO}$ mixing ratios was assessed to range between $2 \%$ (retrieval error) and $15 \%$ (discrepancy with other observations).

The measurements of $\mathrm{CO}$ collected during the spring of 2005 over Asia and the Pacific Ocean correspond to two main observation time periods: 20 March to 10 April and 20 April to 25 May. The ACE CO observed in the upper troposphere above Asia and the Pacific Ocean, averaged over the model $3.75^{\circ} \times 2.5^{\circ}$ grid, is shown in Fig. 3. Enhanced CO values are measured above central and eastern Asia, and extend over the Pacific Ocean to the Western United States, at latitudes ranging from $15^{\circ} \mathrm{N}$ to $60^{\circ} \mathrm{N}$ at $400 \mathrm{hPa}$, and at slightly lower latitudes at $300 \mathrm{hPa}$ (with lower $\mathrm{CO}$ enhancements). These signatures, attributed to pollution outflow from Asia, are further analyzed in Sect. 5.

Additional measurement of $\mathrm{HCN}$, also routinely provided by the ACE-FTS standard retrieval algorithm, and of $\mathrm{C}_{2} \mathrm{H}_{2}$ and $\mathrm{C}_{2} \mathrm{H}_{6}$ from the research version of the retrieval algorithm (Park et al., 2007), are also used to investigate the origin of the air masses by the ACE-FTS.

\subsection{Nadir observations from MOPITT/Terra}

MOPITT (Measurement Of Pollution In The Troposphere) was launched in December 1999 on board the polar orbiting Terra satellite. At nadir, the ground pixel size of the MOPITT measurement is $22 \mathrm{~km} \times 22 \mathrm{~km}$, and the scan angle of $26.1^{\circ}$ across the satellite flight track allows a global coverage in $\sim 3$ days. It measures the infrared radiation in a nadir viewing geometry using gas correlation radiometry. Here, we use the CO data from the Phase II version 3 of the retrieval algorithm, described in Deeter et al. (2003). The 

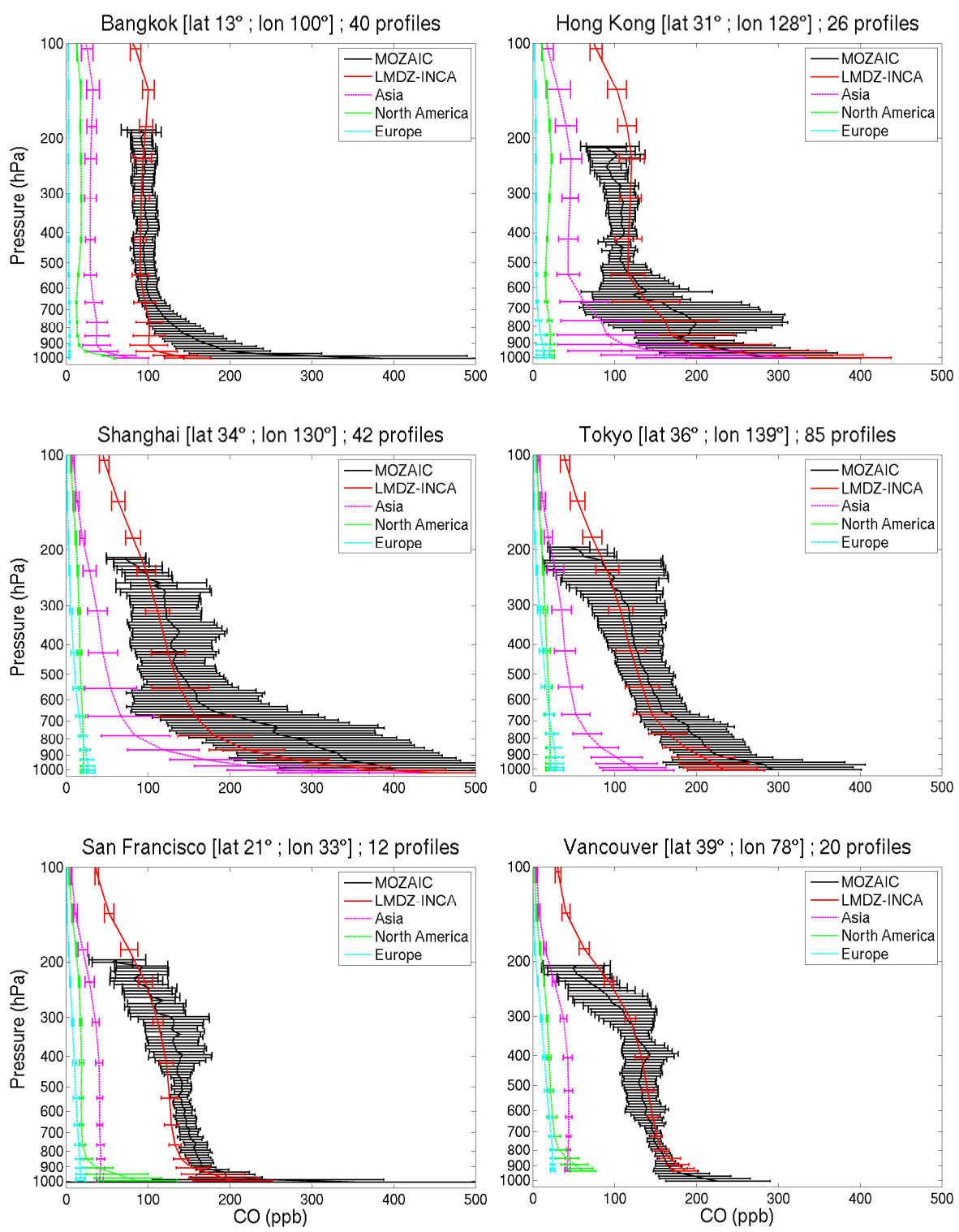

Fig. 2. Comparison between the averaged MOZAIC CO aircraft measurements during March-April-May 2005 (in black) and the corresponding LMDz-INCA simulation (in red) above 4 cities in Asia and 2 in western America. The regional contributions to the model CO are also plotted (contribution from Asia corresponds to the sum of all regions in Fig. 1), as well as the standard deviation of the measured and modeled mixing ratios during the time period.

profiles are retrieved on 7 vertical levels, from the surface to $150 \mathrm{hPa}$ using a nonlinear optimal estimation method. However, the vertical resolution achieved is limited by the observation technique. Although studies have shown that the MOPITT profiles contain information on the $\mathrm{CO}$ vertical structure (Kar et al., 2004), this information is highly correlated. The number of independent pieces of information characterizing the profiles (commonly referred to as degrees of freedom for signal, DOFS) varies from $\sim 2$ in the tropics to less than 1 at high latitudes, weighted towards the middle troposphere (Heald et al., 2003; Deeter et al., 2004). The vertical resolution is estimated to be $\sim 6 \mathrm{~km}$. Retrievals have been validated against aircraft measurements and shown to be biased high by $\sim 6 \%$ for the Phase II retrievals used here (Emmons et al., 2007). As the nighttime measurements have not been validated and appear to be biased relative to the daytime measurements (Heald et al., 2004), only daytime data are considered here.

The total column of $\mathrm{CO}$ observed during the spring of 2005 , averaged over the model $3.75^{\circ} \times 2.5^{\circ}$ grid is mapped in Fig. 4, together with the associated retrieval error. Here again, strong $\mathrm{CO}$ enhancements are observed above eastern 


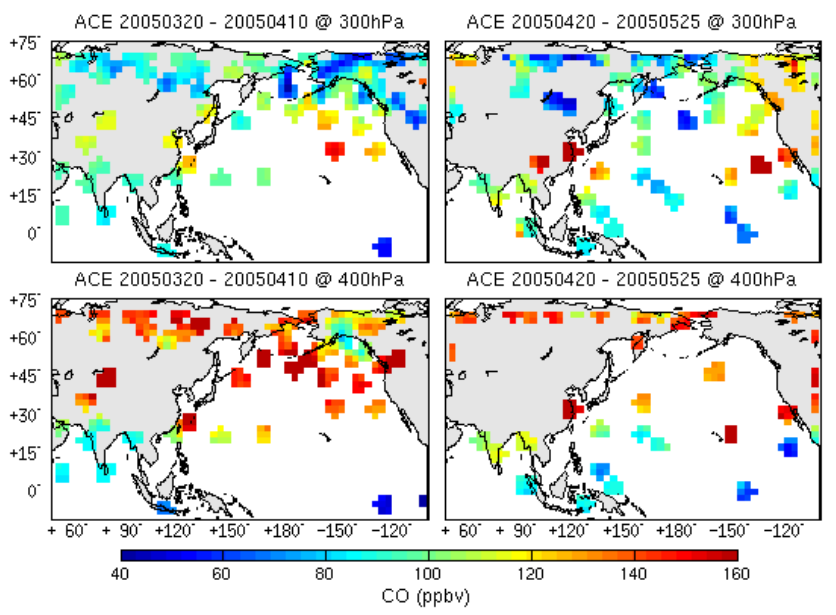

Fig. 3. CO retrieved from ACE-FTS measurements at two upper tropospheric pressure levels (300 and $400 \mathrm{hPa}$ ), averaged over a $3.75^{\circ} \times 2.5^{\circ}$ grid (LMDz-INCA model grid used in this study) for two observation time periods during the spring of 2005 with measurements above the Northern Hemisphere mid-latitudes: 20 March-10 April and 20 April-25 May.

and south-eastern Asia and above the Pacific Ocean. The outflow from Asia is clearly identified above the Pacific Ocean, with a maximum between $\sim 20^{\circ} \mathrm{N}$ to $60^{\circ} \mathrm{N}$. Note that looking at the individual retrieval vertical levels from MOPITT does not change the pattern of the export due to the lack of vertical resolution. The retrieval error is mostly driven by the vertical sensitivity of MOPITT: DOFS strongly depends on surface temperature, with larger DOFS (and hence better vertical resolution) at higher surface temperatures (Deeter et al., 2004), so that the error rapidly increases towards high latitudes (lower signal measured, so larger contribution from the a priori information used during the retrieval).

\subsection{Nadir observations from SCIAMACHY/Envisat}

SCIAMACHY (SCanning Imaging Absorption spectroMeter for Atmospheric CHartographY) was launched in March 2002 on board the ENVISAT satellite, and allows the observation of a number of trace gases with a horizontal resolution of $30 \mathrm{~km} \times 60-120 \mathrm{~km}$.

We use the CO total columns retrieved with the Iterative Maximum Likelihood Method (IMLM) using measurement in the near infrared between 2324.5-2337.9 nm (Gloudemans et al., 2005). This spectral region allows detection down to the Earth's surface, with equal sensitivity to all vertical layers, unlike the thermal infrared region which has a lower sensitivity in the boundary layer. In this paper version 7.4 of the IMLM algorithm is used in which the instrument noise is estimated per individual detector pixel using the dark signal measurements instead of assuming an average value over the whole spectral range as is done in IMLM v6.3 used in de Laat et al. (2006, 2007) and Gloudemans
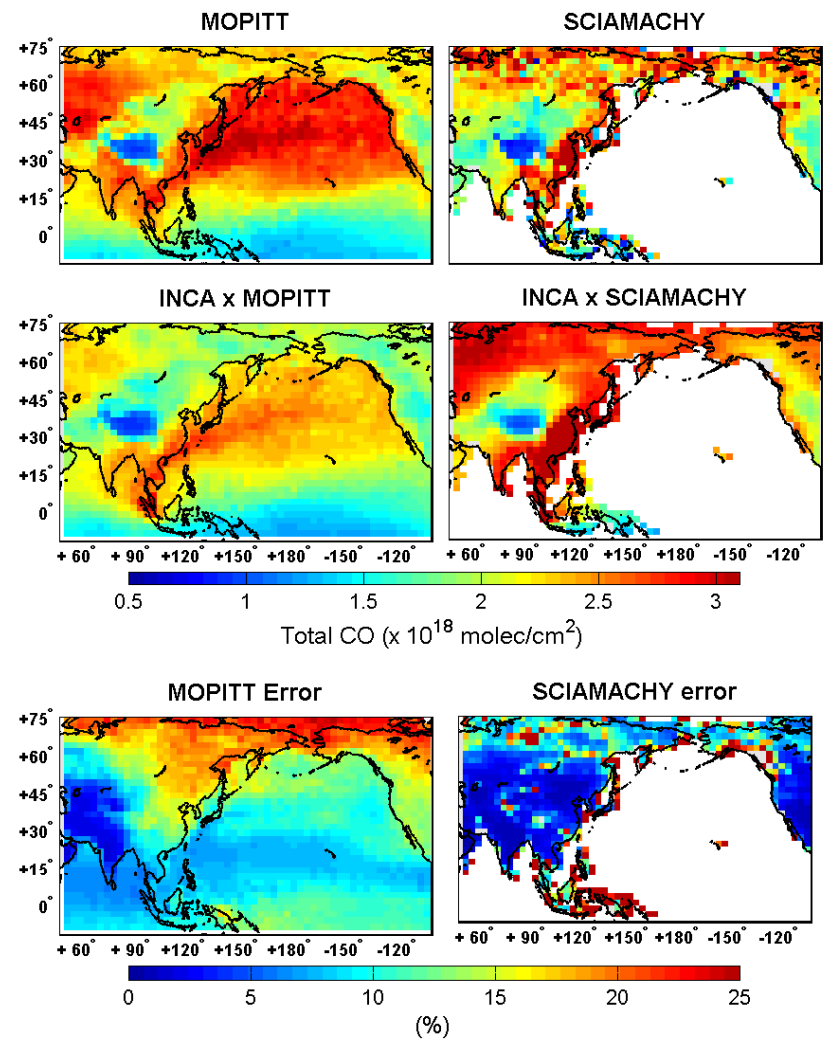

Fig. 4. Total column of CO observed by MOPITT and SCIAMACHY, and corresponding LMDz-INCA model simulations, averaged for March, April and May 2005 over the model grid. For comparison, the INCA profiles collocated with the corresponding data are averaged, after being smoothed using the MOPITT averaging kernels and a priori for comparison with MOPITT data. The MOPITT and SCIAMACHY relative retrieval errors are shown in the bottom panels. White areas correspond to missing or discarded data.

et al. (2006). In addition, this version includes some minor improvements on the calculation of the cross sections. The CO total columns retrieved with IMLM v7.4 are similar to those of v6.3 presented in de Laat et al. (2007), but with a smaller spread in the single measurements. The retrieval error due to random instrument noise can be large, typically $10-100 \%$ depending on the variations in surface albedo and solar zenith angle. Especially over sea the instrument-noise retrieval errors are large, due to the low sea surface reflectance in the near infrared. Therefore measurements over sea and measurements with instrument-noise errors $>1.510^{18} \mathrm{molec} / \mathrm{cm}^{2}$ are excluded from the analysis. The data are filtered using the same selection criteria as in Gloudemans et al. (2006) and are averaged over the whole season on the model $3.75^{\circ} \times 2.5^{\circ}$ grid as recommended in de Laat et al. (2006), using a weighted average based on the instrument-noise retrieval error. Whereas de Laat et al. $(2006,2007)$ only include data with cloud cover 
(a)

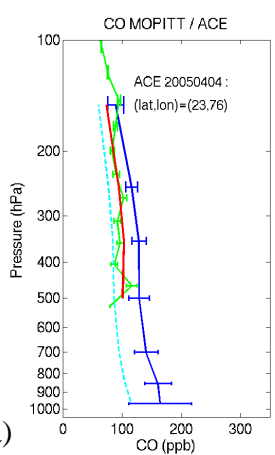

(c)

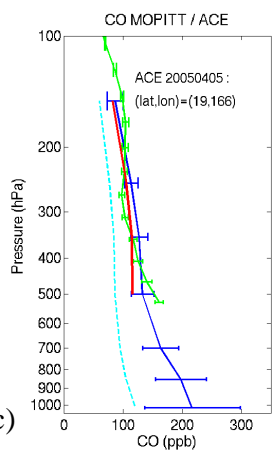

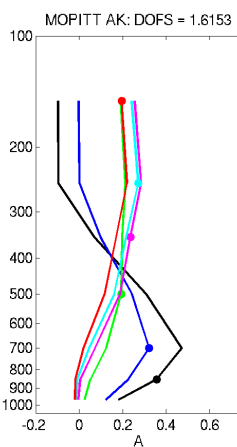

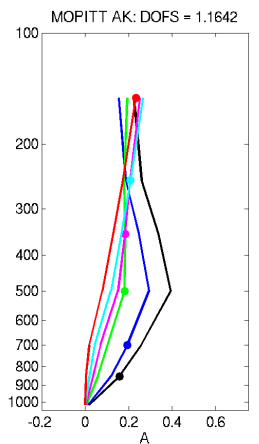

(b)
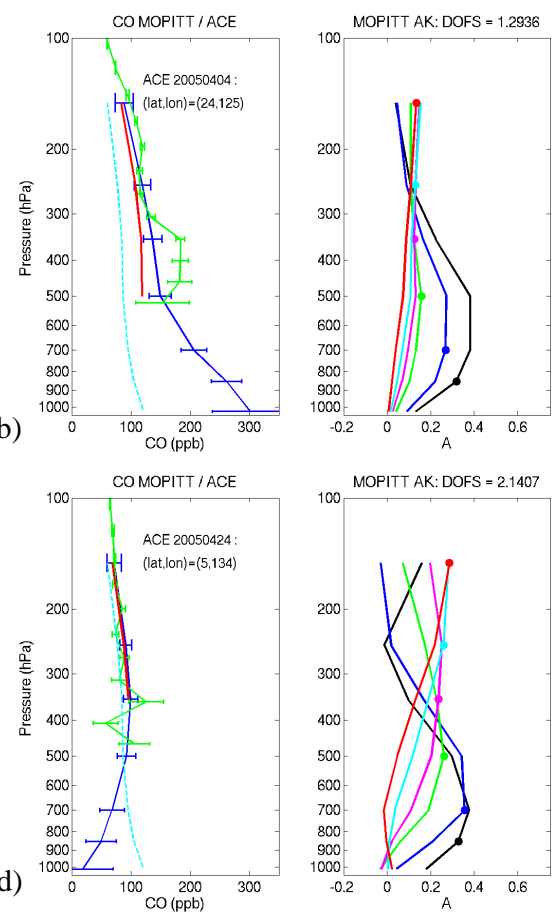

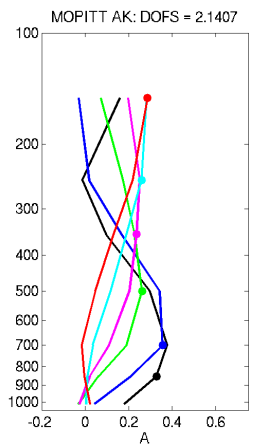

Fig. 5. Examples of ACE-FTS and MOPITT CO profile comparisons for collocated measurements (same day, $\pm 2.5^{\circ}$ ) above Asia and the Pacific Ocean in April 2005. For each comparison, the left panel shows the retrieved profiles (MOPITT retrieval in blue, MOPITT a priori in cyan, ACE-FTS retrieval in green, ACE-FTS retrieval smoothed by MOPITT characteristics in red) and the right one shows the MOPITT averaging kernels.

$<20 \%$, the Gloudemans et al. (2006) selection criteria are used here, including also data over low clouds. Although over low clouds the lowest part of the CO total column is missing, the resulting low bias remains lower than the instrumental signal to noise error, and, in practice, no significant bias is found when comparing the averaged $\mathrm{CO}$ total columns to those based on the de Laat et al. (2006) selection criteria. This suggests that the observations in March-May 2005 contain mostly clouds well below $1.5 \mathrm{~km}$.

The distribution obtained for March-April-May 2005 is shown in Fig. 4. Large enhancements are observed above eastern Asia, reflecting the main source regions. Large values are also observed at high latitudes, probably associated with $\mathrm{CO}$ from the northern mid-latitudes accumulating during the winter. The retrieval error is larger above Indonesia, and generally along the Coast, as well as at latitudes above $60^{\circ} \mathrm{N}$.

\subsection{Intercomparison of $\mathrm{CO}$ satellite observations}

In order to compare vertical profiles retrieved from different instruments, the specific characteristics of each observing system needs to be accounted for. The methodology introduced by Rodgers and Connor (2003) as been used in order to smooth profiles with the higher vertical resolution using the characteristics of lower resolution profiles. These characteristics are represented by the averaging kernel matrix $\mathbf{A}=\partial \hat{\boldsymbol{x}} / \partial \boldsymbol{x}$, corresponding to the sensitivity of the retrieval $\hat{\boldsymbol{x}}$ at each vertical level to the true profile $\boldsymbol{x}$. A is a critical quantity; its rows define the vertical resolution of the retrieval (full width at half maximum), and the trace (sum of diagonal elements) of the matrix defines the number of independent elements that can be retrieved, or the number of degrees of freedom for the signal (DOFS). A smoothed profile is then obtained as follows:

$\boldsymbol{x}_{\text {smoothed }}=\boldsymbol{x}_{a, \text { low }}+\mathbf{A}_{\text {low }}\left(\boldsymbol{x}_{\text {high }}-\boldsymbol{x}_{a, \text { low }}\right)$

where $\boldsymbol{x}_{\text {high }}$ is the high resolution profile, $\boldsymbol{x}_{a, \text { low }}$ is the a priori profile used for the retrieval of the low resolution profile, and $\mathbf{A}_{\text {low }}$ is the averaging kernel matrix characterizing the low resolution profiles.

The vertical resolution of the solar occultation measurements from ACE is much larger than that of the nadir measurements from MOPITT. We use Eq. 1 for the intercomparisons, applying the MOPITT retrieval characteristics to the higher resolution ACE-FTS profiles. ACE-FTS only provides retrievals in the middle and upper troposphere, so that only these levels, and corresponding MOPITT averaging kernels, are used in the comparison. Figure 5 shows several examples of comparisons, before and after applying the smoothing (Eq. 1) using the MOPITT averaging kernels (also plotted in Fig. 5) to the ACE-FTS profiles. Table 1 
Table 1. Comparison (mean relative difference $\bar{\Delta}$ and absolute difference $|\bar{\Delta}|$, standard deviation $\sigma$ and correlation $R^{2}$ ) between MOPITT and ACE (smoothed with the MOPITT characteristics) at collocated retrieval levels for the period March-April-May 2005.

\begin{tabular}{llllll}
\hline MOPITT level (hPa) & $n$ & $\bar{\Delta} *(\%)$ & $|\bar{\Delta}| *(\%)$ & $\sigma(\%)$ & $R^{2}$ \\
\hline 150 & 591 & +18 & 20 & 17 & 0.3 \\
250 & 433 & +18 & 20 & 18 & 0.5 \\
350 & 255 & +18 & 20 & 17 & 0.5 \\
500 & 41 & +16 & 18 & 14 & 0.7 \\
700 & 1 & +48 & 48 & - & - \\
\hline
\end{tabular}

* The relative difference is calculated as follows: $\Delta=\left(\hat{\boldsymbol{x}}_{\text {MOPITT }}-\hat{\boldsymbol{x}}_{\mathrm{ACE}, \text { smoothed }}\right) / \hat{\boldsymbol{x}}_{\mathrm{ACE}, \text { smoothed }}$

summarizes the comparisons at the different levels with collocated data for March-April-May 2005.

First of all, the comparison between the ACE-FTS retrieval and the ACE-FTS smoothed profiles highlights the advantage of such high resolution measurements which can capture the vertical structure of pollution plumes in the upper troposphere. ACE-FTS smoothed and MOPITT are globally in very good agreement considering their respective uncertainty. The relative difference between the two measurements is $\sim 18 \%$ for all levels, with MOPITT giving higher $\mathrm{CO}$ values than ACE-FTS. The best agreement is achieved for MOPITT DOFS $\geq 2$ (i.e., more than 2 independent elements of information contained in the retrieved profile), in the tropical regions (see Fig. 5.d) because the information in the upper troposphere is less correlated to $\mathrm{CO}$ in the lower and middle troposphere. On the contrary, when the DOFS decreases, the MOPITT retrieval levels are all highly correlated, with a maximum sensitivity in the middle troposphere. $\mathrm{CO}$ in the lower/middle troposphere then contributes significantly to the upper troposphere MOPITT retrievals. For these cases, the method used for the comparison becomes questionable. Since the ACE-FTS data do not cover the lower troposphere, this contribution is not included, and this results in an artificially low smoothed ACE-FTS profile, explaining the observed bias. This artifact can be corrected using $\mathrm{CO}$ profiles in the lower troposphere to complete the ACE-FTS profiles at lower altitudes. We verified this using the MOZAIC in situ measurements. However, coincident measurements proved difficult to find and a statistical comparison could not be undertaken.

Since the instrument noise error of single SCIAMACHY CO total column measurements is typically $10-100 \%$, a specific comparison of single $\mathrm{CO}$ observations could not be undertaken. The distributions averaged over the whole period without taking into account the exact spatial and temporal collocations of the SCIAMACHY and MOPITT observations are shown in Fig. 4. They show good general agreement in the observed patterns, with $\mathrm{CO}$ enhancements over eastern Asia and Indonesia associated with anthropogenic and biomass burning emissions. Over high altitude regions such as the Himalayas and the Rocky Mountains, MOPITT and
SCIAMACHY agree well. SCIAMACHY observes larger $\mathrm{CO}$ over large source regions (southern and eastern Asia in particular). This is largely explained by the ability of SCIAMACHY to sound the full vertical column, whereas MOPITT is mostly sensitive to the free troposphere. SCIAMACHY is also larger at high latitudes, which could be explained by surface emissions from biomass burning in Siberia and Canada that are not captured by MOPITT (too low sensitivity), or by transport from Europe at low altitudes over this region. However, this may not be significant since both MOPITT and SCIAMACHY show larger retrieval error at high latitudes. On the contrary, MOPITT CO total columns are larger than those of SCIAMACHY over western Siberia and India. This suggests a bias between the datasets.

\section{Analysis of the Asian outflow}

Pollution is lofted from the Asian boundary layer by three main processes: rapid transport by convection or slower transport by frontal lifting ahead of cold fronts and orographic forcing (Bey et al., 2001; Liang et al., 2004). It is then rapidly advected in the free troposphere by westerly winds. We analyzed the ECMWF horizontal wind fields used to nudge the model simulation as well as the general meteorological conditions. The circulation over the region is driven by the Siberian high leading to a strong north-westerly flow over Northern China, Korea and Japan, with associated cold fronts lifting pollution to the free troposphere. Pollution is also expected to be transported at lower levels behind cold fronts. A high pressure area centered over Eastern Asia induces a south-westerly transport of pollution from this region. It can then be exported to the free troposphere by strong convection over Southern China, allowing rapid transport, or orographic forcing over the Tibetan plateau. Once in the free troposphere, pollution is rapidly transported across the Pacific by westerly winds. The outflow is then driven by the Pacific high around $30^{\circ} \mathrm{N}$, and the low pressure area in the Northern Pacific, centered over western Alaska in March, and moving south-west towards the Aleutian Islands in May. During the time period from 20 March to 10 April, air masses 
are transported to the north-east Pacific, while during the time period from 20 April to 25 May, the transport is confined to lower latitudes, $\sim 30-40^{\circ} \mathrm{N}$. This is consistent with the $\mathrm{CO}$ observed from MOPITT and ACE during these time periods (Figs. 3 and 4).

In this section, we first use the $\mathrm{CO}$ data from MOPITT and SCIAMACHY for a general evaluation of the model over Asia and the Pacific. Comparison between these data and the model $\mathrm{CO}$ are then used to evaluate the Asian emissions. CO observations from MOPITT and ACE-FTS are then compared to the modeled CO to further analyze the export from Asia, and its transport across the Pacific. We then study the origin of the pollution plumes observed by using ACE-FTS measurements of other tropospheric species $\left(\mathrm{C}_{2} \mathrm{H}_{2}, \mathrm{C}_{2} \mathrm{H}_{6}\right.$, $\mathrm{HCN})$.

\subsection{Complementary view from MOPITT and SCIA- MACHY}

In order to get a better insight into the complementary information from the two nadir instruments, we use the model as an intermediate. The averaged comparison over MarchApril-May 2005 is shown in Fig. 4. For comparisons with MOPITT, the model profiles are smoothed according to Eq. 1 in order to get comparable distributions. Since SCIAMACHY is sensitive to the full vertical column, the spatially and temporally collocated modeled and measured total columns are compared directly.

Compared to MOPITT, the modeled CO total column is lower by $8 \%$ on average over Asia and the Pacific $(\sim 1 \%$ at latitudes lower than $20^{\circ} \mathrm{N}, \sim 12 \%$ at mid-latitudes and up to $\sim 16 \%$ over Western Siberia). This underestimate extends to the whole Northern Hemisphere. Although part of this discrepancy could be due to overestimated MOPITT CO (since comparisons with aircraft measurements show a bias of $\sim 6 \%$; Emmons et al., 2007), comparisons of the model results to the MOZAIC aircraft data also showed an underestimate of CO in the free troposphere of $\sim 10-20 \%$. Such an underestimate is a common problem in many global models, as revealed in the intercomparison undertaken by Shindell et al. (2006), who attribute this to a year-round underestimate of emissions from Asia.

On the contrary, the model total $\mathrm{CO}$ tends to be systematically higher than SCIAMACHY (by $24 \%$ on average), especially above eastern India and western Siberia. MOPITT is also higher than SCIAMACHY over these regions. The underestimate of the model CO compared to MOPITT and overestimate compared to SCIAMACHY is partly explained by inconsistencies between MOPITT and SCIAMACHY (SCIAMACHY apparently low compared to MOPITT), as discussed in Sect. 3.4. It could also indicate too large $\mathrm{CO}$ at low altitudes in the model since MOPITT lacks sensitivity in the boundary layer, and could highlight an underestimate of pollution lofting. The model CO remains lower than SCIAMACHY over the largest emission regions (eastern China or the Gange Valley in particular), which could be another indication of too low emissions over Asia. Further evaluation of the Asian emissions and transport with the satellite observations is presented in the following sections.

\subsection{Evaluation of Asian emissions}

As already mentioned, SCIAMACHY and MOPITT CO retrievals are characterized by different vertical sensitivities, inherent to the different spectral regions used: SCIAMACHY is sensitive to the full column, while MOPITT in mainly sensitive to the free troposphere, with low sensitivity in the boundary layer. Clerbaux et al. (2008b) show that enhancements associated with urban pollution can be detected by MOPITT under specific conditions. However, this sensitivity, and hence the contribution from the boundary layer to the MOPITT column, remains low compared to SCIAMACHY. The difference between SCIAMACHY and MOPITT total columns therefore provides information about boundary layer $\mathrm{CO}$, closer to emission sources. Buchwitz et al. (2007) showed that this difference allows a clear identification of pollution enhancements associated with urban areas.

We use these complementary views of the vertical column to qualitatively evaluate the surface emissions over Asia in the model. Therefore, we define a boundary layer residual equal to:

$\mathrm{BLR}=C T_{\text {SCIAMACHY }}-\left(C T_{\text {MOPITT }}-C T_{a}\right)$

where $C T_{\text {SCIAMACHY }}$ is the total column retrieval from SCIAMACHY, $C T_{\text {MOPITT }}$ is the total column retrieved from MOPITT, and $C T_{a}$ is the contribution from the a priori to the MOPITT total column retrieval. The MOPITT and SCIAMACHY data measured during the same day and collocated within the model horizontal resolution are used. This residual is also calculated using the model results, with and without applying the MOPITT averaging kernel to the model profiles. The contribution from the a priori information on the

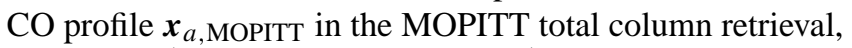
$C T_{a}=\mathbf{T}\left(\left(\mathbf{I}-\mathbf{A}_{\text {MOPITT }}\right) \boldsymbol{x}_{a, \text { MOPITT }}\right)$ with $\mathbf{T}$ the column operator, is removed in order to only keep the part of the column actually observed by MOPITT in the free troposphere. For fully self consistent observations, the residual then corresponds to the additional information on the true state $\mathbf{x}$ provided by SCIAMACHY with respect to MOPITT:

$$
\begin{aligned}
& \mathrm{BLR}=\text { TA }_{\text {SCIAMACHY }} \boldsymbol{x}-\text { TA }_{\text {MOPITT }} \boldsymbol{x} \\
& \approx \mathbf{T}\left(\left(\mathbf{I}-\mathbf{A}_{\text {MOPITT }}\right) \boldsymbol{x}\right)
\end{aligned}
$$

This is true for the model BLR but, since both instruments rely on different observation techniques and retrieval procedures, some inconsistency may result in a bias in the observed BLR. Indeed over remote regions the observed BLR shows a tendency to be lower than the model BLR. We have attempted to remove this bias by assuming that the observed 


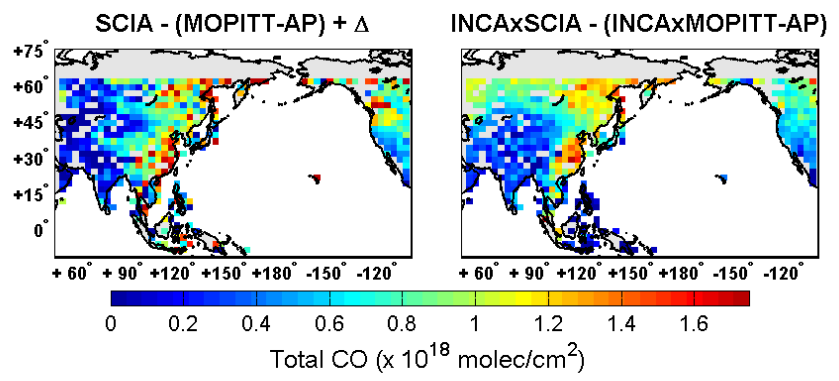

Fig. 6. (SCIAMACHY-MOPITT) boundary layer residual (BLR), observed by the instruments (left), and simulated by the model (right) for March-April-May 2005. Only values for the BLR exceeding the SCIAMACHY and MOPITT errors and at latitudes below $60^{\circ} \mathrm{N}$ are shown (see text for detail). The model values have been constructed in the same way as in Fig. 4 using collocated SCIAMACHY and MOPITT measurements within a $3.75^{\circ} \times 2.5^{\circ}$ grid box only.

BLR over low CO regions far from the sources (chosen to be above west-central Asia, $\sim 40^{\circ} \mathrm{N}, 85^{\circ} \mathrm{E}$, a region close to our region of interest but with no emissions in the model) is equal to the model BLR. The observed BLR is then corrected by addition of a constant amount $\Delta=6.4 \times 10^{17}$ molecules $/ \mathrm{cm}^{2}$. Note that this assumes that the model is correct above westcentral Asia.

The measured and simulated BLR are shown in Fig. 6 for values exceeding the SCIAMACHY and MOPITT errors. Values above $60^{\circ} \mathrm{N}$ are also removed since both instruments show larger uncertainty at high latitudes (Fig. 4). The main pollution source regions are clearly identified in both the measured and the modeled residual. The observed BLR allows a better resolved distribution of the emissions, with large BLR enhancements above the largest cities (particularly clear over China). The model BLR is lower by $\sim 0.33$ molecules $/ \mathrm{cm}^{2}$ over Eastern Asia, which corresponds to $\sim 37 \%$ on average over this region (see Fig. 1 for region limits). Considering the strong uncertainty of this approach, only a qualitative analysis can be undertaken at this point, but this comparison suggests that emissions are underestimated over this region, particularly over large urban areas. The model BLR is also too low above Indonesia, Siberia and south-western Canada, probably due to an underestimate in biomass burning emissions. On the contrary, the model BLR is too large over western Siberia. This could be due to too much transport from Europe at low altitude, as discussed in Sect. 4.3.

Our model simulation is based on the EDGAR inventory, adjusted for $\mathrm{CO}$ using inversion results from Pétron et al. (2004) based on 2001 MOPITT observations. Recent revision of the Asian emission inventories (Streets et al., 2006; Ohara et al., 2007) and inverse modeling work (Kopacz et al., 2008) (allowing higher spatial resolution than previous inversions, including Pétron et al.) also recommend an increase of emissions in Eastern Asia, in eastern and central China in particular. Further work is required in order to allow a quantitative re-evaluation of the emissions: a better understanding of the apparent bias between SCIAMACHY and MOPITT, as well as an inverse analysis accounting for the instrumentnoise error of each measurement would be required, which is beyond the scope of this study.

\subsection{Trans-Pacific transport of $\mathrm{CO}$}

The good spatial and temporal resolutions of the MOPITT data are particularly interesting for the analysis of the spatial patterns and temporal variability of the transport. MOPITT clearly highlights the importance of trans-Pacific transport of pollution in the free troposphere between $\sim 20^{\circ} \mathrm{N}$ and $\sim 60^{\circ} \mathrm{N}$ (Fig. 4). As discussed in Sect. 4.1, the difference between INCA and MOPITT is partially explained by an overestimate in the MOPITT observations, and by an underestimate in the model. This could reveal an underestimate of the long range transport of $\mathrm{CO}$ in the free troposphere, which could be explained by too low surface emissions, as discussed in Sect. 4.2, but also by too low lofting into the free troposphere or too low lifetime.

The ability of the model to simulate the transport events was examined by looking at variations in the total averaged $\mathrm{CO}$ columns during the spring over five boxes, plotted in Fig. 7. The agreement over Eastern Asia is very good, but the model underestimates $\mathrm{CO}$ over the Pacific Ocean and this underestimate tends to increase as the season progresses. This suggests an underestimate, not only of the export from Asia, but maybe also of the net chemical production of $\mathrm{CO}$, which could be due to too large photochemical destruction or too low NMHC concentrations in the model. The good correlation between the model and observations show that the main transport events are captured. Regional tracers show that Asian sources control the temporal variations of $\mathrm{CO}$ over the entire region. The main exporting regions for March-April 2005 are eastern Asia between $\sim 30^{\circ} \mathrm{N}$ and $60^{\circ} \mathrm{N}$ (dominated by fossil fuel combustion), and India and Indonesia at lower latitudes (Fig. 8). The large $\mathrm{CO}$ enhancement over the NorthWestern part of the region (western Siberia) in the MOPITT data is attributed to transport from Europe. In this region, the model CO is larger than the SCIAMACHY total CO. This could reflect a transport at too low altitude of European pollution.

Comparisons between the model and the ACE-FTS CO allow the analysis of the vertical structure of the transport in the middle and upper troposphere. As already highlighted by the comparisons to MOZAIC, the model CO is too high in the upper troposphere and lower stratosphere (UTLS) resulting in large discrepancies compared to ACE-FTS measurements at $400 \mathrm{hPa}$ and $300 \mathrm{hPa}$ at high latitudes (Fig. 9). ACE-FTS shows enhanced CO mixing ratios at mid latitudes corresponding to the location of the Asian outflow. 


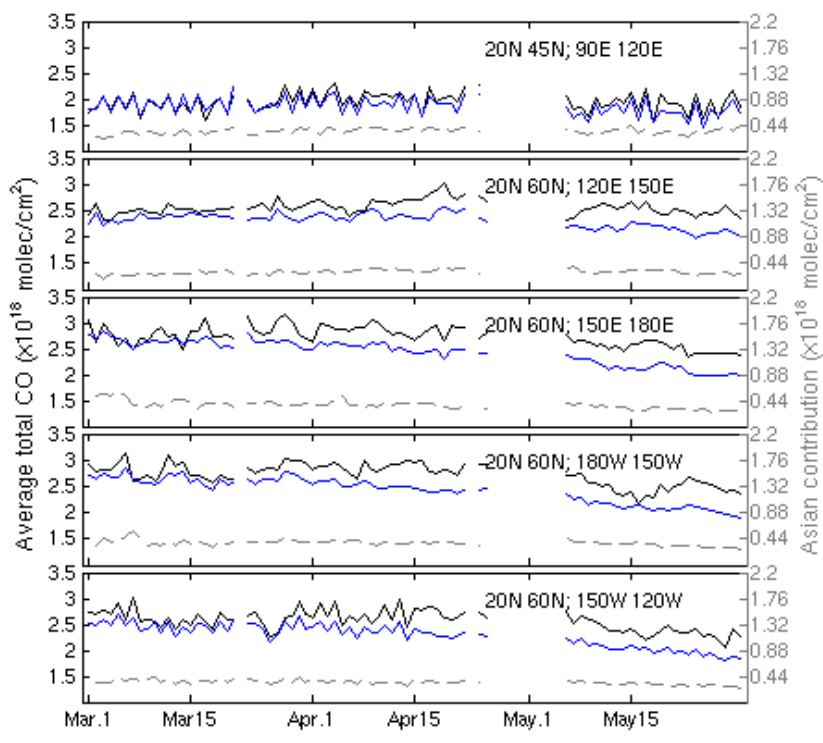

Fig. 7. Variation of the average total CO column observed by the MOPITT instrument (in black) over 5 boxes over Asia and the Pacific Ocean, and corresponding average $\mathrm{CO}$ simulated by LMDzINCA (in blue). The modeled contribution from Asian regional emission tracers (sum of all regions in Fig. 1) is plotted in grey (dashed line). The MOPITT characteristics have been applied to the model simulations. White spaces correspond to data gaps (e.g. between 25 April and 5 May 2005).

The vertical distribution of $\mathrm{CO}$ is shown on cross sections for latitudinal bands over Asia and the Pacific Ocean (Figs. 10 and 11) and illustrates the vertical structure of transport. This representation clearly highlights the lofting of pollution into the free troposphere over eastern and southern Asia and its transport eastward in the free troposphere, as well as the underestimate of the model $\mathrm{CO}$ in the midtroposphere and the overestimate in the UTLS. The main CO enhancements observed by ACE-FTS are captured by the model. Note that the individual ACE-FTS profiles were compared to latitudinal averages in order to get a broader picture of the long range transport, and also to allow for transport errors in the model (plume may not be located in the right grid box). For the first period (20 March-10 April), large CO enhancements are observed above the Pacific Ocean at latitudes $30-60^{\circ} \mathrm{N}$, with $\mathrm{CO}$ typically up to $\sim 200 \mathrm{ppbv}$ around $400 \mathrm{hPa}$ and at slightly higher altitude $(\sim 300 \mathrm{hPa})$ moving eastward. In the region $15-30^{\circ} \mathrm{N}$, ACE-FTS enhancements are found at lower altitude $(\sim 500 \mathrm{hPa})$, consistent with the model showing subsidence over the Ocean. Later in April and May (Fig. 11), large $\mathrm{CO}$ values are observed in the 15$30^{\circ} \mathrm{N}$ latitude band, with two enhancements: one over eastern Asia, associated with rapid vertical transport to the upper troposphere and one further east over the Ocean. The two export branches are clearly seen in the model in this latitude band, and also around $30-45^{\circ} \mathrm{N}$.
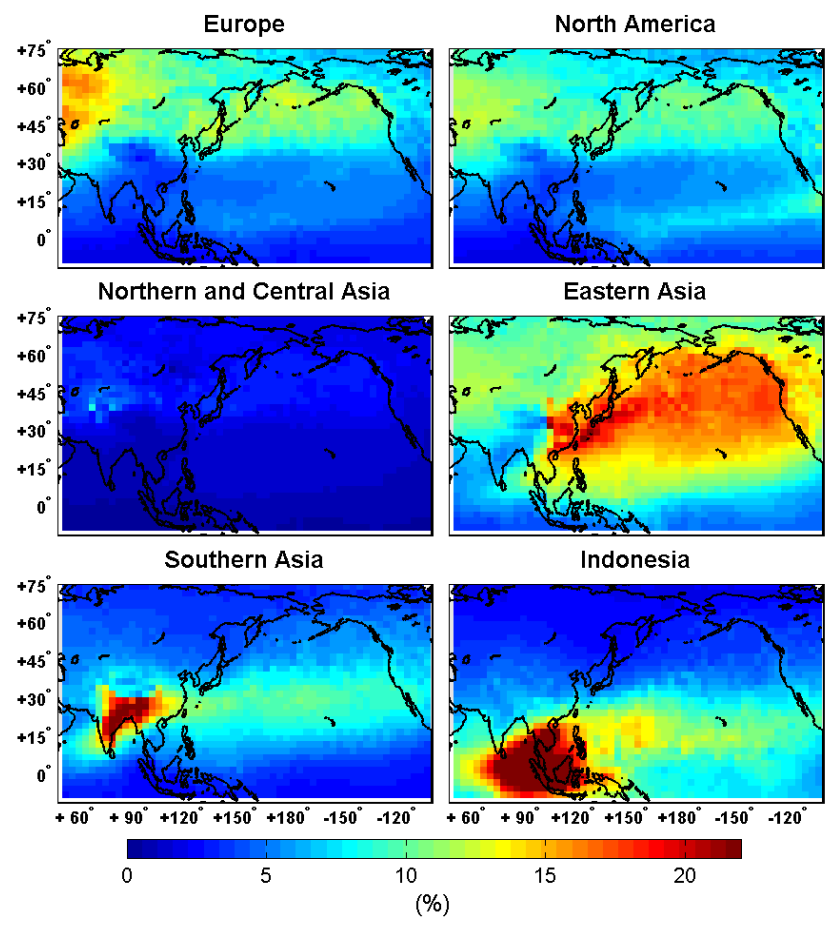

Fig. 8. Averaged relative contributions to the total column CO simulated by INCA, and smoothed using the MOPITT characteristics, from the main Asian source regions (see Fig. 1) as well as from Europe and North America for March-April-May 2005.

20050320-20050410@300hPa

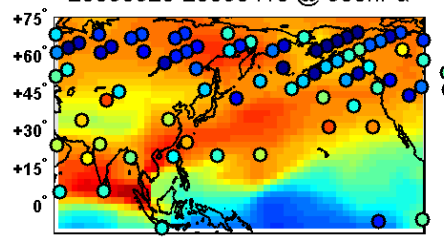

20050320-20050410@ 400hPa

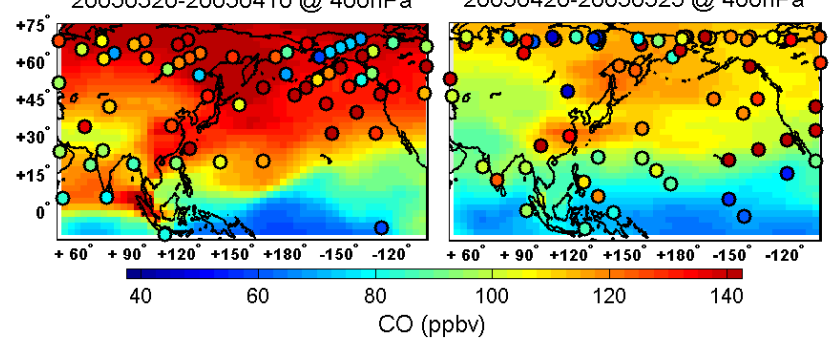

Fig. 9. CO distributions simulated by LMDz-INCA, and ACE-FTS measurements (coloured dots) at the corresponding level for the two ACE measurement periods during the spring of 2005. Note that only days with ACE measurements are included in the LMDzINCA average. 


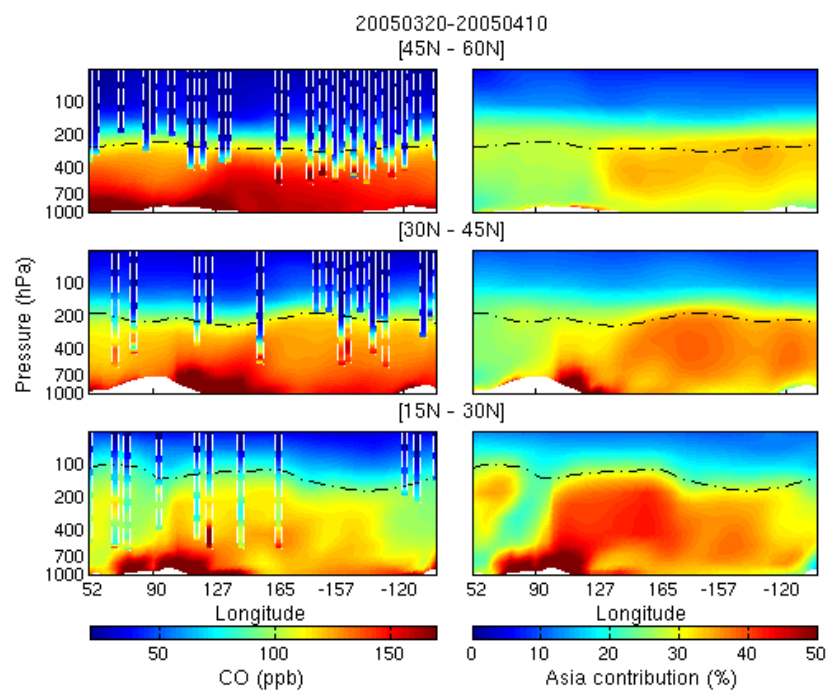

Fig. 10. Left panels: cross section of the model $\mathrm{CO}$ averaged over three latitude bands: $15^{\circ} \mathrm{N}-30^{\circ} \mathrm{N}$ (bottom), $30^{\circ} \mathrm{N}-45^{\circ} \mathrm{N}$ (middle) and $45^{\circ} \mathrm{N}-60^{\circ} \mathrm{N}$ (top) for the time period between 20 March and 20 April 2005 (only days with ACE-FTS measurements are used in the average). The ACE-FTS CO measurements, indicated by the white dashed bars, are plotted on top of the total CO latitudinal average with the same colour code. Right panels: Asian contribution simulated by the model averaged over each latitude band (note the different colour scale). The black dashed line shows the altitude of the tropopause computed with LMDz.

\subsection{Indications for plume origins in the ACE-FTS data}

In addition to a good vertical resolution, ACE provides information on a series of trace gases. Among the other species routinely retrieved from the ACE-FTS measurements are acetylene $\left(\mathrm{C}_{2} \mathrm{H}_{2}\right)$, ethane $\left(\mathrm{C}_{2} \mathrm{H}_{6}\right)$ and hydrogen cyanide $(\mathrm{HCN})$. Examples of averaged profiles measured above the Asian outflow are shown in Fig. 12, together with the main contributions per regions to the total modeled $\mathrm{CO}$.

$\mathrm{C}_{2} \mathrm{H}_{2}, \mathrm{C}_{2} \mathrm{H}_{6}$ and $\mathrm{CO}$ have common sources from combustion and are removed by reaction with $\mathrm{OH}$. However, the mean lifetime of $\mathrm{C}_{2} \mathrm{H}_{2}(\sim 2$ weeks) is much shorter than that of $\mathrm{CO}$ and $\mathrm{C}_{2} \mathrm{H}_{6}$ ( $\sim 2$ months). The relationship between $\mathrm{C}_{2} \mathrm{H}_{2}$ and $\mathrm{CO}$ can be used to study the chemical ageing of air masses (e.g., Smyth et al., 1996; Xiao et al., 2007; Park et al., 2007). Air masses with $\mathrm{C}_{2} \mathrm{H}_{2} / \mathrm{CO}$ ratio greater than $3 \mathrm{ppt} / \mathrm{ppb}$ are considered to correspond to young pollution plumes, containing recent emissions, while ratios lower than $1 \mathrm{ppt} / \mathrm{ppb}$ suggest aged (older than one week) and well mixed plumes (Russo et al., 1999). $\mathrm{CO}, \mathrm{C}_{2} \mathrm{H}_{2}$ and $\mathrm{C}_{2} \mathrm{H}_{6}$ mixing ratios from ACE-FTS, and the corresponding model profiles, are shown in Fig. 12 for four regions over Asia and the Pacific. Note that NMHC emissions were not increased in the simulation presented here, although several studies have pointed to the need to more than double the emissions of NMHC from the EDGAR inventory in extratropical regions

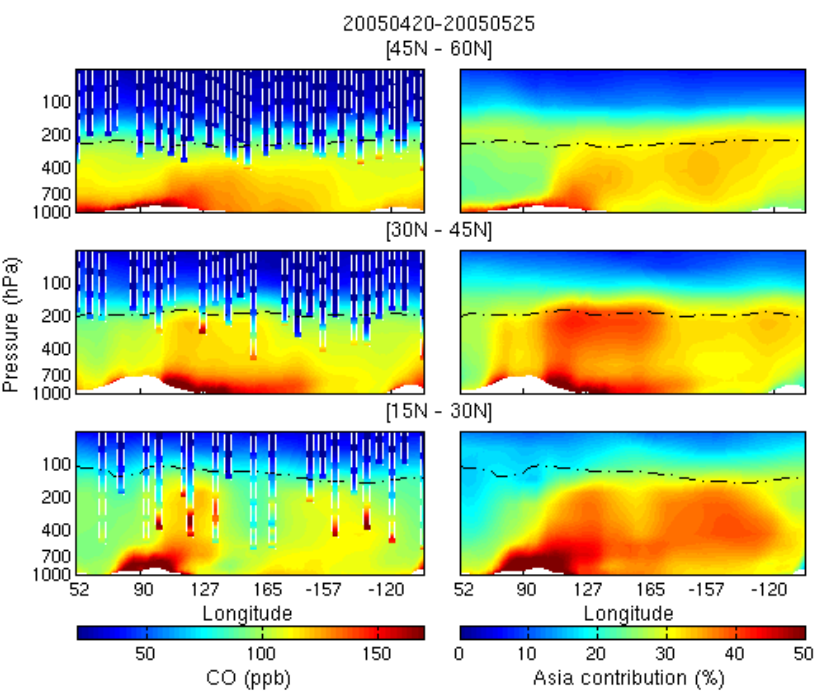

Fig. 11. Same as Fig. 10 but for the time period 20 April25 May 2005

(Streets et al., 2003; Xiao et al., 2007).

The $\mathrm{C}_{2} \mathrm{H}_{2}, \mathrm{C}_{2} \mathrm{H}_{6}$ and $\mathrm{CO}$ profile shapes are well correlated in the observations and in the model, reflecting their common sources. Large $\mathrm{C}_{2} \mathrm{H}_{2} / \mathrm{CO}$ ratios are observed within the $\mathrm{CO}$ plumes, typically around $2 \mathrm{ppt} / \mathrm{ppb}$ above the ocean, but reaching more than $3 \mathrm{ppt} / \mathrm{ppb}$ for observations above the eastern Pacific in the mid-troposphere around $30^{\circ} \mathrm{N}$. This highlights the rapid export and transport across the Pacific Ocean. The regional tracers of $\mathrm{CO}$ indicate that anthropogenic emissions from eastern Asia constitute the main contribution. Transport from Indonesia also has significant contribution in the upper troposphere at low latitudes, while transport from Europe and North America contribute significantly at higher latitudes in the low and middle troposphere. Transport from India is located in the middle troposphere and has a strong impact on the model $\mathrm{CO}$ above Asia, especially at the end of the season, but also above the Pacific.

For $\mathrm{C}_{2} \mathrm{H}_{6}$ and $\mathrm{CO}$, the model is of the correct order of magnitude but underestimates enhancements associated with transport events and overestimates mixing ratios above $\sim 300 \mathrm{hPa}$. The background $\mathrm{C}_{2} \mathrm{H}_{2}$ is correct in the model, but greatly underestimated in the transported plumes, resulting in $\mathrm{C}_{2} \mathrm{H}_{2} / \mathrm{CO}$ ratios too low by a factor of 2 compared to ACE-FTS. This clearly suggests too large diffusion in the model, as discussed for $\mathrm{CO}$ in the previous section. This could also be partly due to underestimated NMHC emissions in the model, which would result in an underestimate of the chemical production of $\mathrm{CO}$. 
(a)
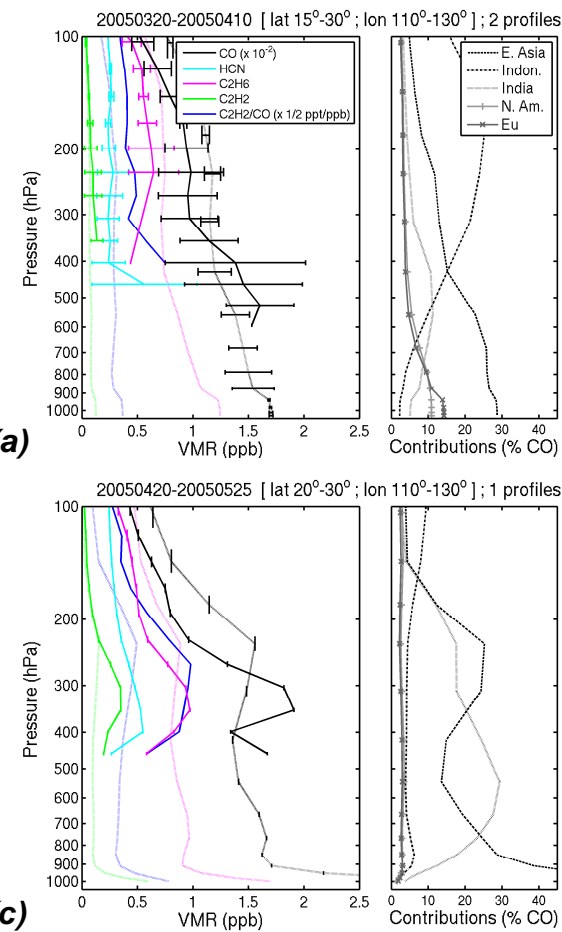
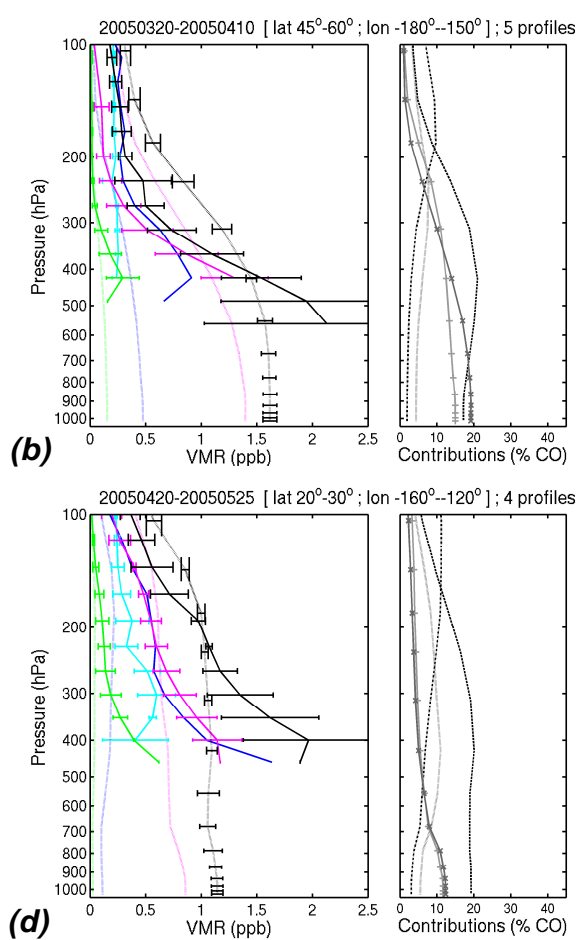

Fig. 12. Averaged volume mixing ratio profiles measured by ACE-FTS above the North Pacific in the Asian outflow for CO (in black), HCN (in cyan), $\mathrm{C}_{2} \mathrm{H}_{6}$ (in magenta) and $\mathrm{C}_{2} \mathrm{H}_{2}$ (in green), and corresponding LMDz-INCA simulation for CO, $\mathrm{C}_{2} \mathrm{H}_{6}$ and $\mathrm{C}_{2} \mathrm{H}_{2}$ (dotted lines). The observed and modeled $\mathrm{C}_{2} \mathrm{H}_{2} / \mathrm{CO}$ profiles are also plotted (blue solid and dotted lines respectively). The main regional contributions to this modeled $\mathrm{CO}$ are shown on the right panels for each location.

The ACE-FTS HCN can be used as a tracer for the identification of biomass burning signatures (Li et al., 2003). Large $\mathrm{HCN}$ mixing ratios were observed between $15^{\circ} \mathrm{N}$ and $30^{\circ} \mathrm{N}$ in the upper troposphere. Enhanced HCN extends to the north-eastern Pacific at lower altitudes in March-April 2005 (400 hPa) but with a small magnitude compared to the large $\mathrm{CO}$ enhancements in this region. The level of the HCN maxima does not always coincide with the $\mathrm{CO}$ enhancements (Fig. 11); it is generally observed at higher altitudes (which is consistent with in situ observations; de Gouw et al., 2004). This indicates that biomass burning is not the most important contribution, especially at high latitudes. However, the correlation increases at lower latitudes, where the biomass burning outflow from southern Asia and Indonesia is expected. Larger HCN mixing ratios are observed during the second time period, extending across the Pacific. The vertical distributions are consistent with the simulated biomass burning signatures of $\mathrm{CO}$ (Fig. 12). However, the lower HCN mixing ratios in March-April than in April-May suggest an increased influence of the fire activity during the season that is not well represented in the model (no such increase in the biomass burning $\mathrm{CO}$ mixing ratios). Figure $12 \mathrm{~d}$ shows profiles measured at mid-latitudes above the eastern Pacific at the end of April 2005, where CO was clearly underestimated in the model (Fig. 9). Large HCN values highlight a strong influence from a biomass burning plume that is not captured in the model, with no clear enhancement of the measured $\mathrm{C}_{2} \mathrm{H}_{2} / \mathrm{CO}$ ratios indicating relatively aged air. This could reflect a strongly underestimated source, but also too large diffusion of a biomass burning plume or underestimated lofting of the biomass burning emissions in Southern Asia.

\section{Summary}

In this study, the export of $\mathrm{CO}$ from Asia was analyzed with the global chemistry and transport model LMDz-INCA based on the complementary pictures provided by the satellite measurements from MOPITT, SCIAMACHY and ACEFTS. In addition to the full NMHC- $\mathrm{CH}_{4}-\mathrm{O}_{3}$ chemistry, $\mathrm{CO}$ regional tracers were included in LMDz-INCA in order to track the signature from the main source regions. The surface emissions from the EDGAR 3.2 inventory have been updated for Asia by scaling emissions above this region to the inverse modeling results by Pétron et al. (2004) (which are based on MOPITT CO for 2001). Evaluation of the model CO simulation against MOZAIC aircraft observations showed an underestimate of $\mathrm{CO}$ by $\sim 10-20 \%$ through the troposphere, especially below $\sim 500 \mathrm{hPa}$ and above $\sim 300 \mathrm{hPa}$. Further analysis of the Asian outflow was undertaken based on the satellite observations. 


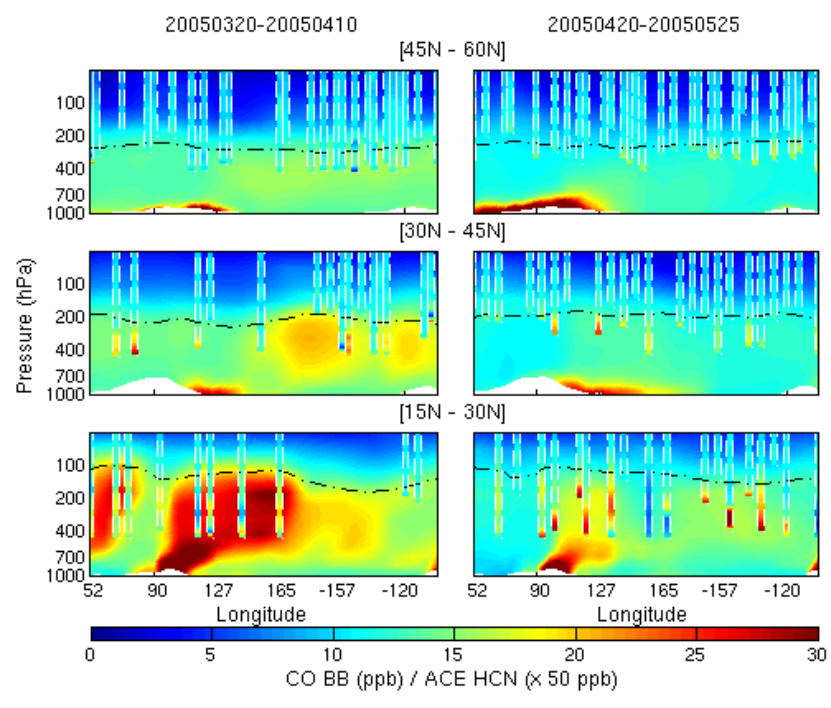

Fig. 13. Model biomass burning $\mathrm{CO}$ cross sections averaged over three latitude bands: $15^{\circ} \mathrm{N}-30^{\circ} \mathrm{N}$ (bottom), $30^{\circ} \mathrm{N}-45^{\circ} \mathrm{N}$ (middle) and $45^{\circ} \mathrm{N}-60^{\circ} \mathrm{N}$ (top) for the time periods 20 March-10 April (left panels) and 20 April-25 May 2005 (right panels). The ACE-FTS HCN measurements are plotted on top of the cross sections and indicated by the white dashed bars. The black dashed line shows the altitude of the tropopause.

MOPITT and SCIAMACHY both use the nadir viewing geometry and provide global $\mathrm{CO}$ distributions with good spatial coverage (typically global every 3 days for MOPITT and 6 days for SCIAMACHY). However, the nadir geometry implies vertically integrated information. Between 1 and 2 pieces of independent information are available in the MOPITT retrievals, with maximum sensitivity in the free troposphere. SCIAMACHY only allows the retrieval of total $\mathrm{CO}$ columns, averaged temporally and/or spatially in order to decrease the random instrument-noise error, but equally sensitive throughout the troposphere. The ACE-FTS solar occultation observations offer valuable information on the vertical structure of the transport in the middle and upper troposphere, in spite of the limited horizontal coverage. An intercomparison of the $\mathrm{CO}$ measurements provided by the three instruments over Asia and the Pacific Ocean highlights their complementary nature and shows the good consistency between the datasets, with an agreement better than $20 \%$ between MOPITT and ACE-FTS in the upper troposphere. Although SCIAMACHY observes larger CO above the largest source regions, consistent with its better sensitivity to the lower altitudes, it tends to be systematically lower than MOPITT above remote regions, except over very high altitude regions, such as the Himalayas and the Rocky Mountains, where the agreement is good. This reveals a bias between the two datasets, which needs further investigation.

Accounting for this bias, the different sensitivities of MOPITT and SCIAMACHY allow the analysis of $\mathrm{CO}$ at low altitudes. Boundary layer residuals (BLR) were obtained by subtracting MOPITT columns (with the contribution from the a priori removed) from the SCIAMACHY total CO. This BLR provides information on the $\mathrm{CO}$ source regions, with, in particular, large enhancements above the main urban areas. The comparison with the corresponding model BLR highlights an underestimate in Asian emissions in the model, in particular above eastern and central China, even after adjustment of the emissions. Recent inventories (Streets et al., 2006) and inverse modeling work (Kopacz et al., 2008) also show that these source regions are underestimated in current inventories, and highlight the rapidly increasing fuel consumption in China (Ohara et al., 2007). Uno et al. (2007) show that model using updated Asian emissions still underestimate sources with respect to the GOME $\mathrm{NO}_{2}$ observations, particularly over China. A more thorough analysis of the possible trends in the $\mathrm{CO}$ observations would be required to better understand the recent evolution of the emissions. Our analysis also suggests an underestimate in emissions over south-east Asia, as well as Siberia and Canada during 2005, probably associated with too low biomass burning emissions. Although the BLR would be an ideal tool for the analysis of surface emissions, a better understanding of the bias between the retrievals from measurements in the two spectral regions (thermal and near IR) is necessary for a quantitative analysis.

The transport of pollution from Asia above the Pacific is clearly observed by MOPITT, with strong CO enhancements extending from $\sim 20^{\circ} \mathrm{N}$ to $\sim 60^{\circ} \mathrm{N}$. This is consistent with the ACE-FTS observations, with values typically reaching $200 \mathrm{ppb}$ around $400-300 \mathrm{hPa}$. Although the model underestimates the total CO by $\sim 8 \%$ compared to MOPITT, the transport patterns and temporal variations are reasonably well captured. The vertical structures simulated by LMDzINCA are consistent with the ACE-FTS observations, and the main pollution features are largely attributed to Asian contributions. However, the model fails to capture the magnitude of these enhancements probably due to underestimated export from $\mathrm{CO}$ source regions, combined with a lack of vertical and horizontal resolution, leading to too large diffusion. LMDz-INCA also predicts too large CO in the UTLS.

In addition to a good vertical resolution, the solar occultation observation mode of the ACE-FTS allows for the detection of a wide variety of chemical species thanks to a high signal to noise ratio. Measurements of acetylene $\left(\mathrm{C}_{2} \mathrm{H}_{2}\right)$, ethane $\left(\mathrm{C}_{2} \mathrm{H}_{6}\right)$ and hydrogen cyanide $(\mathrm{HCN})$ were used in order to further examine the origin of the observed plumes. $\mathrm{C}_{2} \mathrm{H}_{2}$ and $\mathrm{C}_{2} \mathrm{H}_{6}$ are well correlated with the $\mathrm{CO}$ profiles, highlighting common sources and rapid trans-Pacific transport in the upper troposphere. The comparisons between the modeled and observed $\mathrm{C}_{2} \mathrm{H}_{6}$ show the same characteristics as $\mathrm{CO}$ (too high in the UTLS, too low in the transport plumes), but $\mathrm{C}_{2} \mathrm{H}_{2}$ is too low throughout the troposphere, consistent with too low export and too large diffusion in the model.

$\mathrm{HCN}$ is commonly used as a biomass burning tracer. Comparisons between the HCN observations and the model biomass burning signature show good agreement in the 
transport patterns, with strong enhancements in the $15^{\circ} \mathrm{N}-$ $30^{\circ} \mathrm{N}$ latitude band, where the model regional $\mathrm{CO}$ tracers show a large signature from southern Asia and Indonesia, but reveals a possible underestimate in fire activity at the end of the season, and/or too large diffusion of the fire plume in the model. Observed HCN and $\mathrm{CO}$ profiles are not well correlated for measurements at higher latitudes, indicating that biomass burning is not the dominant source. This is in agreement with the predominance of the eastern Asian contribution to the $\mathrm{CO}$ over this region in the model, revealed by the regional $\mathrm{CO}$ tracers.

We have shown that combining information from MOPITT, SCIAMACHY and ACE-FTS provides a complete view of the Asian outflow, from surface emissions to transport in the middle and upper troposphere over the Pacific. Further analysis of the chemical detail provided by the ACEFTS measurements would allow a complete study of the chemical composition of the air masses during export in the UTLS as well as their impact ozone production over the Pacific and further downwind. Assimilation of the observations in the model would be needed to allow quantitative analyses accounting for the specific properties of each dataset, including, in particular, their uncertainties, vertical resolution, and possible biases.

Acknowledgements. S. Turquety was supported by a postdoctoral fellowship from CNES (Centre National d'Etudes Spatiales). P. F. Coheur is research associate with the FRS-FNRS (Belgium). The research in Belgium was funded by the FRS-FNRS (contract F.4511.08), the Belgian Science Policy and the European Space Agency (ESA-Prodex arrangement C90-219). Financial support by the "Actions de Recherche Concertées" (Communauté Française de Belgique) is also acknowledged. The Atmospheric Chemistry Experiment (ACE), also known as SCISAT, is a Canadian-led mission mainly supported by the Canadian Space Agency (CSA) and the Natural Sciences and Engineering Research Council of Canada. SCIAMACHY is a joint project of the German Space Agency DLR and the Dutch Space Agency NIVR with contribution of the Belgian Space Agency. The authors thank the Netherlands SCIAMACHY Data Center and ESA for providing data. The authors acknowledge for their strong support the European Commission, Airbus, CNRSFrance, FZJ-Germany and the airlines (Lufthansa, Air France, Austrian and former Sabena who carry free of charge the MOZAIC instrumentation since 1994). The authors thank G. R. van der Werf (Vrije Universiteit Amsterdam), G. J. Collatz (NASA Goddard Space Flight Center), L. Giglio (SSAI, Maryland), J. T. Randerson (California Institute of Technology) and P. S. Kasibhatla (Duke University) for providing GFED-v2 biomass burning emissions data (http://www.geo.vu.nl/users/gwerf/GFED.htm). The authors also thank Claire Granier for helpful discussions on surface emissions, as well as the two anonymous reviewers for their helpful comments.

Edited by: A. Richter

\section{References}

Akimoto, H.: Global air quality and pollution, Science, 302, 17161719, 2003.

Allen, D., Pickering, K., and Fox-Rabinovitz, M.: Evaluation of pollutant outflow and $\mathrm{CO}$ sources during TRACE-P using modelcalculated, aircraft-based, and Measurements of Pollution in the Troposphere (MOPITT)-derived CO concentrations, J. Geophys. Res., 109, D15S03, doi:10.1029/2003JD004250, 2004.

Arellano, A. F., Kasibhatla, P. S., Giglio, L., van der Werf, G. R., and Randerson, J. T.: Top-down estimates of global CO sources using MOPITT measurements, Geophys. Res. Lett., 31, L01104, doi:10.1029/2003GL018609, 2004.

Bernath P. F., McElroy, C. T., Abrams, M. C., et al.: Atmospheric Chemistry Experiment (ACE): Mission overview, Geophys. Res. Lett., 32, L15S01, doi:10.1029/2005GL022386, 2005.

Bertschi, I. T., Jaffe, D. A., Jaeglé, L., Price, H. U., and Dennison, J. B.: PHOBEA/ITCT 2002 airborne observations of transpacific transport of ozone, $\mathrm{CO}$, volatile organic compounds, and aerosols to the northeast Pacific: Impacts of Asian anthropogenic and Siberian boreal fire emissions, J. Geophys. Res., 109, D23S12, doi:10.1029/2003JD004328, 2004.

Bey, I., Jacob, D. J., Logan, J. A., and Yantosca, R. M.: Asian chemical outflow to the Pacific in spring: Origins, pathways and budgets, J. Geophys. Res., 106, 23 097-23 113, 2001.

Boone, C. D., Nassar, R., Walker, K. A., Rochon, Y., McLeod, S. D., Rinsland, C. P., and Bernath, P. F.: Retrievals for the atmospheric chemistry experiment Fourier-transform spectrometer, Appl. Opt., 44, 7218-7218, 2005.

Buchwitz, M., de Beek, R., Bramstedt, K., Noël, S., Bovensmann, H., and Burrows, J. P.: Global carbon monoxide as retrieved from SCIAMACHY by WFM-DOAS, Atmos. Chem. Phys., 4, 19451960, 2004, http://www.atmos-chem-phys.net/4/1945/2004/.

Buchwitz, M., Khlystova, I., Bovensmann, H., and Burrows, J. P.: Three years of global carbon monoxide from SCIAMACHY: comparison with MOPITT and first results related to the detection of enhanced CO over cities, Atmos. Chem. Phys., 7, 23992411, 2007, http://www.atmos-chem-phys.net/7/2399/2007/.

Clerbaux, C., Coheur, P.-F., Hurtmans, D., Barret, B., Carleer, M., Colin, R., Semeniuk, K., McConnell, J. C., Boone, C., and Bernath, P.: Carbon monoxide distribution from the ACEFTS solar occultation measurements, Geophys. Res. Lett., 32, L16S01, doi:10.1029/2005GL022394, 2005.

Clerbaux, C., Hadji-Lazaro, J., Turquety, S., George, M., Coheur, P.-F., Hurtmans, D., Wespes, C., Herbin, H., Blumstein, D., Tournier, B., and Phulpin, T.: The IASI/MetOp mission: first observations and highlight of its potential contribution to the GMES Earth observation component, Space Research Today (COSPAR Inf. Bul.), 168, 19-24, 2007.

Clerbaux, C., George, M., Turquety S., et al.: CO measurements from the ACE-FTS satellite instrument: data analysis and validation using ground-based, airborne and spaceborne observations, Atmos. Chem. Phys., 8, 2569-2594, 2008a, http://www.atmos-chem-phys.net/8/2569/2008/.

Clerbaux, C., Edwards, D. P., Deeter, M., Emmons, L., Lamarque, J.-F., Tie, X. X., Massie, S. T., and Gille, J.: Carbon monoxide pollution from cities and urban areas observed by the Terra/MOPITT mission, Geophys. Res. Lett., 35, L03817, 
doi:10.1029/2007GL032300, 2008b.

Coheur, P.-F., Herbin, H., Clerbaux, C., Hurtmans, D., Wespes, C., Carleer, M., Turquety, S., Rinsland, C. P., Remedios, J., Hauglustaine, D., Boone, C. D., and Bernath, P.F.: ACE-FTS observation of a young biomass burning plume: first reported measurements of $\mathrm{C}_{2} \mathrm{H}_{4}, \mathrm{C}_{3} \mathrm{H}_{6} \mathrm{O}, \mathrm{H}_{2} \mathrm{CO}$ and PAN by infrared occultation from space, Atmos. Chem. Phys., 7, 5437-5446, 2007, http://www.atmos-chem-phys.net/7/5437/2007/.

Deeter, M. N., Emmons, L. K., Francis, G. L., Edwards, D. P., Gille, J. C., Warner, J. X., Khattatov, B., Ziskin, D., Lamarque, J.-F., Ho, S.-P., Yudin, V., Attié, J.-L., Packman, D., Chen, J., Mao, D., and Drummond, J. R.: Operational carbon monoxide retrieval algorithm and selected results for the MOPITT instrument, J. Geophys. Res., 108(D14), 4399, doi:10.1029/2002JD003186, 2003.

Deeter, M. N., Emmons, L. K., Edwards, D. P., Gille, J. C., and Drummond, J. R.: Vertical resolution and information content of CO profiles retrieved by MOPITT, Geophys. Res. Lett., 31, L15112, doi:10.1029/2004GL020235, 2004.

de Gouw, J. A., Cooper, O. R., Warneke, C., et al.: Chemical composition of air masses transported from Asia to the US West Coast during ITCT 2K2: Fossil fuel combustion versus biomass-burning signatures, J. Geophys. Res., 109, D23S20, doi:10.1029/2003JD004202, 2004.

de Laat, A. T. J., Gloudemans, A. M. S., Schrijver, H., van den Broek, M. M. P., Meirink, J. F., Aben, I., and Krol, M.: Quantitative analysis of SCIAMACHY carbon monoxide total column measurements, Geophys. Res. Lett., 33, L07807, doi:10.1029/2005GL025530, 2006.

de Laat, A. T. J., Gloudemans, A. M. S., Aben, I., Krol, M., Meirink, J. F., van der Werf, G. R., and Schrijver, H.: Scanning Imaging Absorption Spectrometer for Atmospheric Chartography carbon monoxide total columns: Statistical evaluation and comparison with chemistry transport model results, J. Geophys. Res., 112, D12310, doi:10.1029/2006JD008256, 2007.

Dufour, G., Szopa, S., Hauglustaine, D.A., Boone, C. D., Rinsland, C. P., and Bernath, P. F.: The influence of biogenic emissions on upper-tropospheric methanol as revealed from space, Atmos. Chem. Phys., 7, 6119-6129, 2007,

http://www.atmos-chem-phys.net/7/6119/2007/.

Edwards, D. P., Emmons, L. K., Hauglustaine, D. A., et al.: Observations of carbon monoxide and aerosols from the Terra satellite: Northern Hemisphere variability, J. Geophys. Res., 109, D24202, doi:10.1029/2004JD004727, 2004.

Emanuel, K. A. and Zivkovic-Rothman, M.: Development and evaluation of a convection scheme for use in climate models. J. Atmos. Sci., 56, 1766-1782, 1999.

Emmons, L. K., Pfister, G. G., Edwards, D. P., Gille, J. C., Sachse, G., Blake, D., Wofsy, S., Gerbig, C., Matross, D., and Nédélec, P.: Measurements of Pollution in the Troposphere (MOPITT) validation exercises during summer 2004 field campaigns over North America, J. Geophys. Res., 112, D12S02, doi:10.1029/2006JD007833, 2007.

Folberth, G., Hauglustaine, D. A., Lathière, J., and Brocheton, F.: Impact of biogenic hydrocarbons on tropospheric chemistry: Results from a global chemistry-climate model, Atmos. Chem. Phys., 6, 2273-2319, 2006,

http://www.atmos-chem-phys.net/6/2273/2006/.

Folkins, I., Bernath, P., Boone, C., Donner, L.J., Eldering, A., Lesins, G., Martin, R.V., Sinnhuber, B.-M., and Walker,
K.: Testing convective parameterizations with tropical measurements of $\mathrm{HNO} 3, \mathrm{CO}, \mathrm{H}_{2} \mathrm{O}$, and $\mathrm{O}_{3}$ : Implications for the water vapor budget, J. Geophys. Res., Vol. 111, D23304, doi:10.1029/2006JD007325, 2006.

Frankenberg, C., Platt, U., and Wagner, T.: Retrieval of CO from SCIAMACHY onboard ENVISAT: detection of strongly polluted areas and seasonal patterns in global CO abundances, Atmos. Chem. Phys., 5, 1639-1644, 2005,

http://www.atmos-chem-phys.net/5/1639/2005/.

Funke, B., López-Puertas, M., Bermejo-Pantaleón, D., von Clarmann, T., Stiller, G. P., Höpfner M., Grabowski, U., and Kaufmann, M.: Analysis of nonlocal thermodynamic equilibrium CO $4.7 \mu \mathrm{m}$ fundamental, isotopic, and hot band emissions measured by theMichelson Interferometer for Passive Atmospheric Sounding on Envisat, J. Geophys. Res., 112, D11305, doi:10.1029/2006JD007933, 2007.

Gloudemans, A. M. S., Schrijver, H., Kleipool, Q., van den Broek, M. M. P., Straume, A. G., Lichtenberg, G., van Hees, R. M., Aben, I., and Meirink, J. F.: The impact of SCIAMACHY nearinfrared instrument calibration on $\mathrm{CH}_{4}$ and $\mathrm{CO}$ total columns, Atmos. Chem. Phys., 5, 2369-2383, 2005,

http://www.atmos-chem-phys.net/5/2369/2005/.

Gloudemans, A. M. S., Krol, M. C. , Meirink, J. F., de Laat, A. T. J., van der Werf, G. R., Schrijver, H., van den Broek, M. M. P., and Aben, I.: Evidence for long-range transport of carbon monoxide in the Southern Hemisphere from SCIAMACHY observations, Geophys. Res. Lett., 33, L16807, doi:10.1029/2006GL026804, 2006.

Hauglustaine, D. A., Hourdin, F., Walters, S., Jourdain, L., Filiberti, M.-A., Larmarque, J.-F., and Holland, E. A.: Interactive chemistry in the Laboratoire de Météorologie Dynamique general circulation model : description and background tropospheric chemistry evaluation, J. Geophys. Res., 109, D04314, doi:10.1029/3JD003957, 2004.

Heald, C.L., Jacob, D. J., Fiore, A. M., et al.: Asian outflow and transpacific transport of carbon monoxide and ozone pollution: An integrated satellite, aircraft and model perspective, J. Geophys. Res., 108(D24), 4804, doi:10.1029/2003JD003507, 2003.

Heald, C. L., Jacob, D. J., Jones, D. B. A., Palmer, P. I., Logan, J. A., Streets, D. G., Sachse, G. W., Gille, J. C., Hoffman, R. N., and Nehrkorn, T.: Comparative inverse analysis of satellite (MOPITT) and aircraft (TRACE-P) observations to estimate Asian sources of carbon monoxide, J. Geophys. Res., 109, D23306, doi:10.1029/2004JD005185, 2004.

Heald, C. L., Jacob, D. J., Park, R. J., Alexander, B., Fairlie, T. D., Yantosca, R. M., and Chu, D. A.: Transpacific transport of Asian anthropogenic aerosols and its impact on surface air quality in the United States, J. Geophys. Res., 111, D14310, doi:10.1029/2005JD006847, 2006.

Hudman, R. C., Jacob, D. J., Cooper, O. R., et al.: Ozone production in transpacific Asian pollution plumes and implications for ozone air quality in California, J. Geophys. Res., 109 (D23), D23S10, doi:10.1029/2004JD004974, 2004.

Jacob, D. J., Crawford, J. H., Kleb, M. M., Connors, V. S., Bendura, R. J., Raper, J. L., Sachse, G. W., Gille, J. C., Emmons, L., and Heald, C. L.: Transport and Chemical Evolution over the Pacific (TRACE-P) aircraft mission: Design, execution, and first results, J. Geophys. Res., 108(D20), 9000, doi:10.1029/2002JD003276, 2003. 
Jaffe, D.A., Anderson, T., Covert, D., Kotchenruther, R., Trost, B., Danielson, J., Simpson, W., Berntsen, T., Karlsdottir, S., Blake, D., Harris, J., Carmichael, G., and Uno, I.: Transport of Asian Air Pollution to North America, Geophys. Res. Lett., 26, 711714, 1999.

Jaffe, D. A., Bertschi, I., Jaeglé, L., Novelli, P., Reid, J. S., Tanimoto, H., Vingarzan, R., and Westphal, D.: Long-range transport of Siberian biomass burning emissions and impact on surface ozone in western North America, Geophys. Res. Lett., 31, L16106, doi:10.1029/2004GL020093, 2004.

Jiang, J. H., Livesey, N. J., Su, H., Neary, L., McConnell, J. C., and Richards, N. A. D.: Connecting surface emissions, convective uplifting, and long-range transport of carbon monoxide in the upper troposphere: New observations from the Aura Microwave Limb Sounder, Geophys. Res. Lett., 34, L18812, doi:10.1029/2007GL030638, 2007.

Kar, J., Bremer, H., Drummond, J. R., et al.: Evidence of vertical transport of carbon monoxide from Measurements of Pollution in the Troposphere (MOPITT), Geophys. Res. Lett., 31, L23105, doi:10.1029/2004GL021128, 2004.

Kopacz, M., Jacob, D. J., Henze, D.K., Heald, C.L., Streets, D.G., and Zhang, Q.: Comparison of adjoint and analytical Bayesian inversion methods for constraining Asian sources of carbon monoxide using satellite (MOPITT) measurements of CO columns, J. Geophys. Res., 113, doi:10.1029/2007JD009264, in press, 2008.

Li, Q. B., Jacob, D. J., Yantosca, R. M., Heald, C. L., Singh, H. B., Koike, M., Zhao, Y., Sachse, G. W., and Streets, D. G.: A global 3-D model evaluation of the atmospheric budgets of $\mathrm{HCN}$ and $\mathrm{CH}_{3} \mathrm{CN}$ : Constraints from aircraft measurements over the western Pacific, J. Geophys. Res., 108, 8827, doi:10.1029/2002JD003075, 2003.

Li, Q. B., Jiang, J. H., Wu, D. L., Read, W. G., Livesey, N. J., Waters, J. W., Zhang, Y. S., Wang, B., Filipiak, M. J., Davis, C. P., Turquety, S., Wu, S. L., Park, R. J., Yantosca, R. M., and Jacob, D. J.: Convective outflow of South Asian pollution: A global CTM simulation compared with Aura MLS observations, Geophys. Res. Lett., 32, L14826, doi:10.1029/2005GL022762, 2005.

Liang, Q., Jaeglé, L., Jaffe, D. A., Weiss-Penzias, P., Heckman, A., and Snow, J. A.: Long-range transport of Asian pollution to the northeast Pacific: Seasonal variations and transport pathways of carbon monoxide, J. Geophys. Res., 109, D23S07, doi:10.1029/2003JD004402, 2004.

Luo, M., Rinsland, C. P., Rodgers, C. D., Logan, J. A., Worden, H., Kulawik, S., Eldering, A., Goldman, A., Shephard, M. W., Gunson, M., and Lampel, M.: Comparison of carbon monoxide measurements by TES and MOPITT: Influence of a priori data and instrument characteristics on nadir atmospheric species retrievals, J. Geophys. Res., 112, D09303, doi:10.1029/2006JD007663, 2007.

Martin, R. V., Jacob, D. J., Chance, K., Kurosu, T. P., Palmer, P. I., and Evans, M. J.: Global inventory of nitrogen oxide emissions constrained by space-based observations of $\mathrm{NO}_{2}$ columns, J. Geophys. Res., 108(D17), 4537, doi:10.1029/2003JD003453, 2003.

McMillan, W. W., Barnet, C., Strow, L., Chahine, M. T., McCourt, M. L., Warner, J. X., Novelli, P. C., Korontzi, S., Maddy, E. S., and Datta, S.: Daily global maps of carbon monoxide from
NASA's Atmospheric Infrared Sounder, Geophys. Res. Lett., 32, L11801, doi:10.1029/2004GL021821, 2005.

Nedelec, P., Cammas, J. P., Thouret, V., Athier, G., Cousin, J. M., Legrand, C., Abonnel, C., Lecoeur, F., Cayez, G., and Marizy, C.: An improved infra-red carbon monoxide analyser for routine measurements aboard commercial Airbus aircraft: Technical validation and first scientific results of the MOZAIC program, Atmos. Chem. Phys., 3, 1551-1564, 2003,

http://www.atmos-chem-phys.net/3/1551/2003/.

Novelli, P. C., Steele, L. P., and Tans, P. P.: Mixing ratios of carbon monoxide in the troposphere, J. Geophys. Res., 97, 20731 $20750,1992$.

Ohara, T., Akimoto, H., Kurokawa, J., Horii, N., Yamaji, K., Yan, X., and Hayasaka, T.: An Asian emission inventory of anthropogenic emission sources for the period 1980-2020, Atmos. Chem. Phys., 7, 4419-4444, 2007,

http://www.atmos-chem-phys.net/7/4419/2007/.

Olivier, J. G. J. and Berdowski, J. J. M.: Global emissions sources and sinks, in: The Climate System, edited by: Berdowski, J., Guicherit, R. and B.J. Heij, 33-78, A.A. Balkema Publishers/Swets \& Zeitlinger Publishers, Lisse, The Netherlands. ISBN 905809255 0, 2001.

Park, M., Randel, W. J., Emmons, L. K., Bernath, P. F., Walker, K. A., and Boone, C. D.: Chemical isolation in the Asian monsoon anticyclone observed in Atmospheric Chemistry Experiment (ACE-FTS) data, Atmos. Chem. Phys., 8, 757-764, 2008, http://www.atmos-chem-phys.net/8/757/2008/.

Parrish, D. D., Kondo, Y., Cooper, O. R., Brock, C. A., Jaffe, D. A., Trainer, M., Ogawa, T., Hübler, G., and Fehsenfeld, F. C.: Intercontinental Transport and Chemical Transformation 2002 (ITCT 2K2) and Pacific Exploration of Asian Continental Emission (PEACE) experiments: An overview of the 2002 winter and spring intensives, J. Geophys. Res., 109, D23S01, doi:10.1029/2004JD004980, 2004.

Pétron, G., Granier, C., Khattatov, B., Yudin, V., Lamarque, J., Emmons, L., Gille, J., and Edwards, D. P.: Monthly CO surface sources inventory based on the 2000 2001 MOPITT satellite data, Geophys. Res. Lett., 31, L21107, doi:10.1029/2004GL020560, 2004.

Pumphrey, H. C., Filipiak, M. J., Livesey, N. J., Schwartz, M. J., Boone, C., Walker, K. A., Bernath, P., Ricaud, P., Barret B., Clerbaux, C., Jarnot, R. F., Manney, G. L., and Waters, J. W.: Validation of middle-atmosphere carbon monoxide retrievals from MLS on Aura, J. Geophys. Res., 112, D24S38, doi:10.1029/2007JD008723, 2007.

Richter, A., Burrows, J. P., Nüß, H., Granier, C., and Niemeier, U.: Increase in tropospheric nitrogen dioxide over China observed from space, Nature, 437(1), 129-132, doi:10.1038/nature04092, 2005.

Rinsland, C. P, Luo, M., Logan, J. A., Beer, R., Worden, H., Kulawik, S. S., Rider, D., Osterman, G., Gunson, M., Eldering, A., Goldman, A., Shephard, M., Clough, S. A., Rodgers, C., Lampel, M., and Chiou, L.: Nadir measurements of carbon monoxide (CO) distributions by the tropospheric emission spectrometer instrument onboard the Aura spacecraft: Overview of analysis approach and examples of initial results, Geophys. Res. Lett., 33, L22806, doi:10.1029/2006GL027000, 2006a.

Rinsland, C. P., Boone, C.D., Bernath, P.F., Mahieu, E., Zander, R., Dufour, G., Clerbaux, C., Turquety, S., Chiou, L., Mc- 
Connell, J.C., Neary, L., and Kaminski, J. W.: First space-based observations of formic acid $(\mathrm{HCOOH})$ : Atmospheric Chemistry Experiment austral spring 2004 and 2005 Southern Hemisphere tropical-mid-latitude upper tropospheric measurements, Geophys. Res. Lett., 33, L23804, doi:10.1029/2006GL027128, $2006 b$.

Rinsland, C. P., Dufour, G., Boone, C. D., Bernath, P. F., Chiou, L., Coheur, P.-F., Turquety, S., and Clerbaux, C.: Satellite boreal measurements over Alaska and Canada during June-July 2004: Simultaneous measurements of upper tropospheric CO, $\mathrm{C}_{2} \mathrm{H}_{6}, \mathrm{HCN}, \mathrm{CH}_{3} \mathrm{Cl}, \mathrm{CH}_{4}, \mathrm{C}_{2} \mathrm{H}_{2}, \mathrm{CH}_{3} \mathrm{OH}, \mathrm{HCOOH}$, OCS, and SF6 mixing ratios, Global Biogeochem. Cycles, 21, GB3008, doi:10.1029/2006GB002795, 2007.

Rodgers C. D. and Connor, B. J.: Intercomparison of remote sounding instruments, J. Geophys. Res., 108(D3), 4116, doi:10.1029/2002JD002299, 2003.

Russo, R. S., Talbot, R. W., Dibb, J. E., et al.: Chemical composition of Asian continental outflow over the western $\mathrm{Pa}$ cific: Results from Transport and Chemical Evolution over the Pacific (TRACE-P), J. Geophys. Res., 108(D20), 8804, doi:10.1029/2002JD003184, 2003.

Shindell, D. T., G. Faluvegi, D. S. Stevenson, et al.: Multimodel simulations of carbon monoxide: Comparison with observations and projected near-future changes, J. Geophys. Res., 111, D19306, doi:10.1029/2006JD007100, 2006.

Smyth, S., Bradshaw, J., Sandholm, S., et al.: Comparison of free tropospheric western Pacific air mass classification schemes for the PEM-West A experiment, J. Geophys. Res., 101(D1), 17431762, 1996.

Stohl, A., Eckhardt, S., Forster, C., James, P., and Spichtinger, N.: On the pathways and time-scales of intercontinental air pollution transport, J. Geophys. Res., 107, 4684, doi:10.1029/2001JD001396, 2002.

Streets, D. G. and Waldhoff, S. T.: Present and future emissions of air pollutants in China: SO2, NOx, and CO, Atmos. Environ., 34, 363-374, doi:10.1016/S1352-2310(99)00167-3, 2000.

Streets, D. G., Zhang, Q., Wang, L., He, K., Hao, J., Wu, Y., Tang, Y., and Carmichael, G. R.: Revisiting China's CO emissions after the Transport and Chemical Evolution over the Pacific (TRACE-P) mission: Synthesis of inventories, atmospheric modeling, and observations, J. Geophys. Res., 111, D14306, doi:10.1029/2006JD007118, 2006.
Szopa, S., Hauglustaine, D. A., and Ciais, P.: Relative contributions of biomass burning emissions and atmospheric transport to carbon monoxide interannual variability, Geophys. Res. Lett., 34, L18810, doi:10.1029/2007GL030231, 2007.

Turquety, S., Hadji-Lazaro, J., Clerbaux, C., Hauglustaine, D. A., Clough, S. A., Cassé, V., Shlüssel, P., and Mégie, G.: Operational trace gas retrieval algorithm for the Infrared Atmospheric Sounding Interferometer, J. Geophys. Res., 109, D21301, 10.1029/2004JD00482, 2004.

Uno, I., He, Y., Ohara, T., Yamaji, K., Kurokawa, J.-I., Katayama, M., Wang, Z., Noguchi, K., Hayashida, S., Richter, A., and Burrows, J. P.: Systematic analysis of interannual and seasonal variations of model-simulated tropospheric $\mathrm{NO}_{2}$ in Asia and comparison with GOME-satellite data, Atmos. Chem. Phys., 7, 16711681, 2007, http://www.atmos-chem-phys.net/7/1671/2007/.

van der Werf, G. R., Randerson, J. T. , Giglio, L. , Collatz, G. J. , Kasibhatla, P. S. , and Arellano Jr., A. F.: Interannual variability in global biomass burning emissions from 1997 to 2004, Atmos. Chem. Phys., 6, 3423-3441, 2006,

http://www.atmos-chem-phys.net/6/3423/2006/.

von Clarmann, T., Glatthor, N., Stiller, G. P., Grabowski, U., Höpfner, M., Kellmann, S., Linden, A., Milz, M., Steck, T., Fischer, H., Funke, B., and Koukouli, M. E.: MIPAS measurements of upper tropospheric $\mathrm{C}_{2} \mathrm{H}_{6}$ and $\mathrm{O}_{3}$ during the Southern hemispheric biomass burning season in 2003, Atmos. Chem. Phys., 7, 5861-5872, 2007, http://www.atmos-chem-phys.net/7/5861/2007/.

Wild, O. and Akimoto, H.: Intercontinental transport of ozone and its precursors in a three-dimensional global CTM, J. Geophys. Res., 106, 27 729-27 744, 2001.

Xiao, Y., Jacob, D. J., and Turquety, S.: Atmospheric acetylene and its relationship with $\mathrm{CO}$ as an indicator of air mass age, J. Geophys. Res., 112, D12305, doi:10.1029/2006JD008268, 2007. 